\title{
An individual-based model of bay anchovy population dynamics in the mesohaline region of Chesapeake Bay
}

\author{
Kenneth A. Rose ${ }^{1, *}$, James H. Cowan Jr ${ }^{2}$, Mark E. Clark ${ }^{1}$, Edward D. Houde ${ }^{3}$, \\ Shyh-Bin Wang ${ }^{2}$
}

${ }^{1}$ Coastal Fisheries Institute and Department of Oceanography and Coastal Sciences, Louisiana State University, Baton Rouge, Louisiana 70803, USA

${ }^{2}$ University of South Alabama, Dauphin Island Sea Lab, 101 Bienville Blvd, Dauphin Island, Alabama 36528, USA

${ }^{3}$ Chesapeake Biological Laboratory, University of Maryland Center for Environmental Science, PO Box 38, Solomons, Maryland 20688-0038, USA

\begin{abstract}
Bay anchovy Anchoa mitichilli population dynamics in the mesohaline region of Chesapeake Bay are described and analyzed with an individual-based model. The model begins with spawning by individual females and simulates the daily growth and mortality of each female's progeny as they develop through the egg, yolk-sac larva, (feeding) larval, juvenile, and adult stages in a single, well-mixed compartment. The model runs for $50 \mathrm{yr}$. Eggs and yolk-sac larvae develop at rates dependent on temperature, and die at fixed daily rates. All feeding individuals (larvae, juveniles, and adults) consume zooplankton and grow according to defined bioenergetics relationships. Encounters, attacks and captures of prey, and the probability that feeding individuals will die are treated stochastically using Monte Carlo techniques. Net immigration of spawners into the modelled box each year is simulated in 2 ways: multiplier of survivors and as a constant number. Model predictions of stage-specific growth and survival rates, and diets were similar for multiplier and constant immigration simulations, and both were similar to observed values. Density-dependent growth of larvae and juveniles led to a negative relationship between mean length and number of recruits and to density-dependent survival of larvae and juveniles. Density-dependent growth was due to anchovy consumption reducing prey densities, and not due to temperature effects on numbers surviving and growth. First-year survivorship was lower in years of high egg production than in years of low egg production. Larval growth and survival rates were positively related to recruitment, but the reverse was true for juveniles. Years of high recruitment were not years of high first-feeder production, but rather were years of high larval survival. The model simulates a single spatial box with a forced net immigration of spawners and assumes density-independent spawning and mortality processes. The model quantifies the basic processes leading to recruitment of bay anchovy and sets the stage to explore potential compensatory responses of anchovy.
\end{abstract}

KEY WORDS: Bay anchovy · Chesapeake Bay · Population dynamics · Individual-based model

\section{INTRODUCTION}

Understanding population dynamics of bay anchovy Anchoa mitichilli is important because this species is important in many estuarine food webs, may be impacted by anthropogenic stresses, and represents a common life history strategy. Bay anchovy is an oppor-

•E-mail: karose@lsu.edu tunistic life history strategist (Winemiller \& Rose 1992), exhibiting early maturation, batch spawning, rapid larval growth, and rapid population turnover. Bay anchovy is the most abundant fish in Chesapeake Bay, and perhaps along the South Atlantic and Gulf of Mexico Coasts of the USA. (Houde \& Zastrow 1991). In the Chesapeake Bay, bay anchovy is a major consumer of zooplankton and is a dominant forage item of commercially and recreationally important fish (Baird \& Ulanowicz 1989, Houde \& Zastrow 1991, Hartman \& 
Brandt 1995). Many anchovy reside in Chesapeake Bay throughout their lives, making them especially suspectible to anthropogenic stresses. Effects of power plant entrainment and impingement on bay anchovy have been the focus of much attention (Polgar et al. 1988, Summers 1989, Loos \& Perry 1991). Understanding the dynamics of this abundant, short-lived species can provide information on factors controlling population dynamics of other similar, but less well-studied, fish.

Quantitative population modeling of bay anchovy in Chesapeake Bay is possible because there is considerable knowledge of all life stages based upon information from laboratory and field research (see Houde \& Zastrow 1991). Ecological models which have included bay anchovy include: energy budgets of young-of-theyear (YOY) cohorts in Chesapeake Bay (Luo \& Brandt 1993), power plant entrainment effects on YOY cohorts imbedded in a hydrodynamic model (Polgar et al. 1988), and anchovy biomass dynamics over a 3 yr period as part of a compartment model of the forage fish community in the Patuxent River (Summers 1989) and as 1 of 33 components in a steady-state energy flux analysis of Chesapeake Bay (Baird \& Ulanowicz 1989).

In this paper, we present an individual-based model of the population dynamics of bay anchovy in a wellmixed compartment configured for the mesohaline region of Chesapeake Bay. Feeding, growth, mortality, and spawning are followed daily in $50 \mathrm{yr}$ simulations. Model simulations are analyzed to identify effects of temperature and anchovy density on recruitment. Additional model analyses that explore potential compensatory responses are presented in Cowan et al. (1999, in this issue) and Wang et al. (1997).

\section{METHODS: MODEL DESCRIPTION}

Model overview. The model begins with spawning of individual females and simulates the growth and mortality of each female's progeny as they develop through the egg, yolk-sac larva, (feeding) larval, juvenile, and adult stages. Exogenous feeding begins with the larval stage ( 2 to $3 \mathrm{~mm}$ ); juveniles are from 25 to 40 mm; adults are $>40 \mathrm{~mm}$. Individuals are followed as they grow, spawn, and die on a daily time step. Surviving female adults become spawners of next year's progeny. Two alternative assumptions for an annual migratory influx of anchovy into the mesohaline region from the southern portion of the Chesapeake Bay are represented: multiplier and constant immigration. Under multipler immigration, the number of annual immigrants is a multiplier of the number of survivors in the mesohaline region each year. Under constant immigration, a fixed number of immigrants is added to the population each year. Individuals can live for more than 1 yr; however, due to high mortality, individuals rarely live to Age 4 in simulations. The model represents these daily dynamics in a single, well-mixed compartment $(10 \mathrm{~m} \times 20 \mathrm{~m} \times 7.5 \mathrm{~m}$ deep). Model simulations are for $50 \mathrm{yr}$, with each 365-day year beginning on Calendar Day 135 (May 15), the beginning of the spawning season.

Eggs and yolk-sac larvae develop at rates dependent on temperature, and die at fixed daily rates. All feeding individuals (larvae, juveniles, and adults) consume zooplankton, and grow according to defined bioenergetics relationships. Prey encounters, attacks and captures, and mortality (probability of dying) of feeding individuals are treated stochastically and determined using Monte Carlo techniques.

For the egg and yolk-sac larva stages, each day's spawn of eggs (from pooled females) is followed through time; individuals are followed through larval, juvenile, and adult stages. The model tracks each individual's length $(L, \mathrm{~mm})$, dry weight $(W, \mathrm{mg})$, age (d), life stage, day spawned, and day hatched.

Environmental conditions in the compartment are daily mean water temperature, fraction of the $24 \mathrm{~h}$ day that is daylight, and the daily densities of zooplankton prey. For this version of the model, environmental and biological conditions are based upon information from the mesohaline region of the Chesapeake Bay (Table 1).

Many processes in the model include the influences of anchovy size, environmental variables, or anchovy density. Individuals must attain $40 \mathrm{~mm}$ to become mature. Fecundity (eggs per batch) increases, while mortality rate and vulnerability to starvation decrease, with increasing anchovy size. Growth is represented with a bioenergetics equation in which maximum consumption and metabolism depend on fish weight and water temperature. Realized consumption is computed with a foraging algorithm; search volume and prey capture success, and therefore diet breadth, increase with anchovy size. Density-dependent growth can arise from bay anchovy consumption exceeding prey turnover rate and lowering prey densities. Slower growth can lead to density-dependent survival by prolonging the amount of time individuals spend in highmortality, early life stages, and can lead to densitydependent reproduction by causing younger age of maturation and greater eggs per spawning batch.

Daily temperature and daylight. Daily temperatures $\left(T,{ }^{\circ} \mathrm{C}\right)$ for each $365 \mathrm{~d}$ year are generated by stochastically assigning values of coefficients to a regression equation fit to multiple years of observed temperatures. The regression equation is

$$
T=\beta_{0}-\beta_{1} \cos (0.0172 d a y)-\beta_{2} \sin (0.0172 d a y)
$$


Table 1. Data sources used to formulate the individual-based bay anchovy model

\begin{tabular}{|c|c|}
\hline Variable & Description and sources \\
\hline $\begin{array}{l}\text { Water temperature } \\
\text { (Eq.1) }\end{array}$ & $\begin{array}{l}\text { Regression of temperature on day of year using } 7 \text { yr of } 5 \mathrm{~d} \mathrm{wk}^{-1} \text { temperatures measured } \\
\text { near the mouth of the Patuxent River ( } \mathrm{H} \text {. Millsaps unpubl. data, Chesapeake Biological Lab } \\
\text { Solomons, MD) }\end{array}$ \\
\hline Spawning start days & $\begin{array}{l}\text { Anchovy spawn in Chesapeake Bay from May to September (Luo \& Musick 1991, Zastrow } \\
\text { et al. 1991). By varying the start days, simulated egg production slowly increases at the } \\
\text { beginning of the season }\end{array}$ \\
\hline $\begin{array}{l}\text { Maximum number } \\
\text { of batch spawns }\end{array}$ & $\begin{array}{l}\text { Average number of batches have been estimated as } 50 \text { to } 55 \text { (Luo \& Musick 1991, Zastrow } \\
\text { et al. 1991). Varying the maximum number of batches allows for simulated egg production } \\
\text { to slowly decrease near the end of the season as females reach their individual maximum } \\
\text { bouts on different days. Assigned maximum number of batches was set to slightly higher } \\
\text { values than observed average numbers because water temperatures in some years preven } \\
\text { the maximum number of batches from being realized }\end{array}$ \\
\hline $\begin{array}{l}\text { Egg development rate } \\
\text { (Eq. 5) }\end{array}$ & $\begin{array}{l}\text { Egg development rate, as a function of temperature, was fit using regression to laboratory } \\
\text { data reported in Tucker (1989) }\end{array}$ \\
\hline $\begin{array}{l}\text { Yolk-sac development rate } \\
\text { (Eq. } 6 \text { ) }\end{array}$ & $\begin{array}{l}\text { Yolk-sac larval development rate as a function of temperature was determined by regres- } \\
\text { sion analysis of laboratory experiments on the number of days from hatching to eye pigmen- } \\
\text { tation at various constant temperatures (Houde 1974) }\end{array}$ \\
\hline Egg mortality & $\begin{array}{l}\text { Reported anchovy egg mortality rates are: } 86 \% \mathrm{~d}^{-1} \text { (Leak \& Houde } 1987 \text { ); } 50 \% \mathrm{~d}^{-1} \text { (Houde } \\
\text { 1987); } 80 \% \mathrm{~d}^{-1} \text { (Dorsey 1993); } 72 \text { to } 82 \% \mathrm{~d}^{-1} \text { (PSE\&G 1984); and } 75 \text { to } 80 \% \text { (Houde et al. } \\
\text { 1994, Dorsey et al. 1996) }\end{array}$ \\
\hline Yolk-sac larval mortality & $\begin{array}{l}\text { Yolk-sac larvae die at lower rates (about } 0.01 \text { to } 0.02 \mathrm{~h}^{-1} \text { less) than eggs; mortality rate of } \\
\text { yolk-sac larvae averaged } 72 \% \mathrm{~d}^{-1} \text { during } 12 \mathrm{~d} \text { in July } 1991 \text { at locations of anchovy spawning } \\
\text { in Chesapeake Bay (Dorsey } 1993 \text {, Dorsey et al. 1996) }\end{array}$ \\
\hline $\begin{array}{l}\text { Length-weight relationship } \\
\text { (Eq. } 7 \text { ) }\end{array}$ & $\begin{array}{l}\text { Length-weight relationships were fit separately to laboratory data for early larvae (Houde } 8 \\
\text { Sheckter 1981) and to Chesapeake Bay field data for adults (Newberger 1989) }\end{array}$ \\
\hline $\begin{array}{l}\text { Maximum consumption }\left(C_{\max }\right) \\
\text { (Eq. 11) }\end{array}$ & $\begin{array}{l}C_{\max } \text { as a function of weight based on regression that combined laboratory consumption } \\
\text { rates under high prey densities for }<12 \mathrm{~mm} \text { larvae (Houde \& Sheckter 1981, 1983) and } \\
\text { consumption rates for } \sim 50 \mathrm{~mm} \text { adults (Vazquez 1989) }\end{array}$ \\
\hline $\begin{array}{l}\text { Optimal and maximum } \\
\text { temperature parameters for } \\
C_{\max }[F(T) \text { in Eq. } 11]\end{array}$ & $\begin{array}{l}\text { Values of optimal and maximum temperatures are similar to those reported for bay anchovy } \\
\text { (Houde \& Zastrow 1991) }\end{array}$ \\
\hline $\begin{array}{l}\text { Utilization efficiency } \\
\text { (Eq. 12) }\end{array}$ & $\begin{array}{l}\text { Evidence suggests that utilization efficiency increases with size or age during early larval } \\
\text { development (Govoni et al. 1986). Utilization efficiencies of less than } 36 \% \text { have been } \\
\text { estimated for early larvae of bay anchovy based upon laboratory-derived energy budgets } \\
\text { (Houde \& Sheckter 1983, Tucker 1989). Utilization efficiencies of bay anchovy adults range } \\
\text { from } 27 \text { to } 81 \% \text {, the lower values occurring at very high rations ( } 40 \% \text { body weight } \mathrm{d}^{-1} \text { ) } \\
\text { (Vazquez 1989) }\end{array}$ \\
\hline $\begin{array}{l}\text { Routine metabolism } \\
\text { (Eq. 14) }\end{array}$ & $\begin{array}{l}\text { Routine metabolism as a function of weight was based on a regression that combined lab- } \\
\text { oratory measurements of oxygen consumption for }<0.2 \mathrm{mg} \text { dry weight anchovy (Houde } \& \\
\text { Schekter (1983) and oxygen consumption values for anchovy adults (Vazquez 1989) }\end{array}$ \\
\hline $\begin{array}{l}\delta \text { adjustment } \\
(\text { Eq. } 16)\end{array}$ & $\begin{array}{l}\delta \text { was specified to result in starvation after } 5 \mathrm{~d} \text { of no feeding to agree with laboratory starva- } \\
\text { tion experiments. Complete mortality of unfed bay anchovy larvae occurred in the labora. } \\
\text { tory } 3 \text { to } 5 \mathrm{~d} \text { after hatching and } 2.5 \text { to } 4 \mathrm{~d} \text { after eye pigmentation at } 24 \text { to } 32^{\circ} \mathrm{C} \text { (Houde } 1974 \text { ) }\end{array}$ \\
\hline $\begin{array}{l}\text { Cumulative distribution } \\
\text { functions (CDFs) for zoo- } \\
\text { plankton prey types (Fig. 3) }\end{array}$ & $\begin{array}{l}C D F \text { s for tintinnid/rotifer and nauplii were estimated by non-linear fitting of empirical } \\
\text { functions to monthly net samples ( } 44 \mu \mathrm{m} \text { mesh) from } 1985 \text { to } 1989 \text { at } 2 \text { stations in the meso- } \\
\text { haline Chesapeake Bay off Calvert Cliffs (S. Brownlee, The Academy of Natural Sciences, } \\
\text { Benedict, MD, pers. comm.). CDFs for copepodite and adult copepods were estimated by } \\
\text { non-linear fitting of empirical functions to monthly samples at stations off Calvert Cliffs from } \\
1976 \text { to } 1980 \text { based on } 757 \text { l pump samples taken from the surface to } 10 \mathrm{~m} \text { depth (Olson } \\
\text { 1987). Developing CDFs by season resulted in different mean densities for each season, but } \\
\text { once normalized for the seasonal mean density, similar shaped CDFs for all seasons }\end{array}$ \\
\hline $\begin{array}{l}\text { Angle of acuity }(\alpha) \\
(\text { Eq. } 20)\end{array}$ & $\begin{array}{l}\alpha \text { as function of fish length was a regression fit to data by Breck \& Gitter (1983) from clear } \\
\text { water experiments on bluegills Lepomis macrochirus ranging in length from about } 10 \text { to } \\
160 \mathrm{~mm} \text {; such information is not available for bay anchovy. Reported reaction distances of a } \\
\text { variety of species of fish larvae (<20 mm) are approximately } 0.33 \text { to } 1 \text { body lengths (Blaxter } \\
\text { 1986), compared to the predicted values (from Eqs. } 19 \& 20 \text { ) of } 0.21 \text { body lengths for a } 3 \mathrm{~mm} \\
\text { anchovy larva eating tintinnids and rotifers and } 0.45 \text { to } 1.8 \text { body lengths for a } 15 \mathrm{~mm}\end{array}$ \\
\hline
\end{tabular}


Table 1 (continued)

\begin{tabular}{|c|c|}
\hline Variable & Description and sources \\
\hline & $\begin{array}{l}\text { anchovy larva eating nauplii and copepodites. A } 50 \mathrm{~mm} \text { adult searching for adult copepods } \\
\text { has an } R D \text { of } 160 \mathrm{~mm} \text { ( } 3.1 \text { body lengths). Values of angle of acuity }(\alpha) \text { predicted by Eq. (20) } \\
\text { are similar to values measured for larvae and juveniles of other species (Guma'a 1982, } \\
\text { Hairston et al. } 1982 \text {, Noakes \& Godin } 1988 \text {. Wanzenbock \& Schiemer 1989) }\end{array}$ \\
\hline $\begin{array}{l}\text { Turbidity factor } \\
\text { (Eq. 21) }\end{array}$ & $\begin{array}{l}\text { The turbidity factor reduces RDs by multipyling by } 0.8 \text { to } 0.4 \text {. Vinyard \& O'Brien (1976) } \\
\text { reported } R D \text { s of bluegills that were } 50 \text { to } 25 \% \text { of those determined in clear water for turbid- } \\
\text { ities similar to those observed in the Chesapeake Bay }\end{array}$ \\
\hline $\begin{array}{l}\text { Capture probabilities } \\
\text { (Eq. } 22 \text {, Fig. } 4 \text { ) }\end{array}$ & $\begin{array}{l}\text { Capture probabilities are based on functions fitted by eye to general patterns of capture } \\
\text { success reported for marine fish larvae (Blaxter 1986), for bay anchovy larvae (Houde \& } \\
\text { Schekter 1980, Tucker 1989), and from gut content and prey selectivity studies of bay } \\
\text { anchovy in the Chesapeake Bay (see Houde \& Zastrow 1991, Klebasko 1991) }\end{array}$ \\
\hline $\begin{array}{l}\text { Zooplankton equiliblrium } \\
\text { densities (Eqs. } 17 \& 24, \text { Fig. 6) }\end{array}$ & $\begin{array}{l}\text { Equilibrium densities for zooplankton were determined from the same Chesapeake Bay } \\
\text { field data (Olson } 1987 \text {, S. Brownlee pers. comm.) used to estimate CDFs (Fig. } 5 \text { ). Equilibrium } \\
\text { densities of tintinnids and rotifers are set to } 10 \text { times the mean observed density to account } \\
\text { for net extrusion (Brownlee \& Jacobs 1987). Equilibrium densities as functions of day were } \\
\text { non-linear fits of empirical functions }\end{array}$ \\
\hline $\begin{array}{l}\text { Zooplankton maximum turn- } \\
\text { over rates (Eq. 24; Table 2) }\end{array}$ & $\begin{array}{l}\text { Specified maximum zooplankton turnover rates are similar to values observed in the field } \\
\text { with zooplankton densities close to equilibrium densities. We multiply by } 2 \text { in Eq. (24) to } \\
\text { obtain these rates at one-half of equilibrium densities. Durbin \& Durbin }(1981) \text { report turn- } \\
\text { over rates of about } 0.1 \text { to } 0.5 \mathrm{~d}^{-1} \text { for Acartia hudsonica during the spring }\left(5 \text { to } 15^{\circ} \mathrm{C}\right) \text { and } 0.7 \\
\text { to } 1.1 \mathrm{~d}^{-1} \text { for Acartia tonsa during the summer }\left(17 \text { to } 22^{\circ} \mathrm{C}\right) \text { in Narragansell Bay. During the } \\
\text { summer (average of } 25.5^{\circ} \mathrm{C} \text { ) in the Patuxent River, Heinle }(1966) \text { estimated turnover rates for } \\
\text { Acartia tonsa nauplii of } 0.56 \mathrm{~d}^{-1} \text { and about } 0.4 \mathrm{~d}^{-1} \text { for copepodites and adults. Regression } \\
\text { equations based upon a review of marine copepod turnover rates and temperature give } \\
\text { rates of } 0.07 \text { to } 0.17 \mathrm{~d}^{-1} \text { at } 12^{\circ} \mathrm{C}, 0.15 \text { to } 0.41 \mathrm{~d}^{-1} \text { at } 20^{\circ} \mathrm{C} \text {, and } 0.24 \text { to } 0.75 \mathrm{~d}^{-1} \text { at } 25.5^{\circ} \mathrm{C} \\
\text { (Huntley \& Lopez 1992) }\end{array}$ \\
\hline $\begin{array}{l}\text { Weight threshold for } \\
\text { starvation }\end{array}$ & $\begin{array}{l}\text { The weight thresholds of } 0.65 \text { for larvae and } 0.5 \text { for juveniles and adults are typical based } \\
\text { upon results from a variety of fish species (Rogers \& Westin 1981. Shuter et al. 1989, } \\
\text { Johnson \& Evans 1991, Letcher et al. 1996) }\end{array}$ \\
\hline $\begin{array}{l}\text { Juvenile and adult } \\
\text { mortality rates }\end{array}$ & $\begin{array}{l}\text { Assigned mortality rates of } 0.032 \mathrm{~d}^{-1} \text { for juveniles and } 0.005 \text { to } 0.0095 \mathrm{~d}^{-1} \text { for adults are } \\
\text { similar to reported rates: } 0.01 \mathrm{~d}^{-1} \text { for juvenile to Age } 1 \text { (Houde } 1987 \text { ); adult rates of } 0.006 \text { to } \\
0.008 \mathrm{~d}^{-1} \text { based upon catch curve analysis and } 0.003 \text { to } 0.004 \mathrm{~d}^{-1} \text { from life history models } \\
\text { (Newberger 1989); adult rates of } 0.003 \text { to } 0.006 \mathrm{~d}^{-1} \text { (PSE\&G 1984); and a juvenile rate of } \\
0.035 \mathrm{~d}^{-1} \text { and adult rates of } 0.004 \text { to } 0.007 \mathrm{~d}^{-1} \text { based upon catch-curve analysis of trawl and } \\
\text { acoustics-adjusted data (Wang 1992) }\end{array}$ \\
\hline
\end{tabular}

where day $=$ calendar day; and $\beta_{0}, \beta_{1}$, and $\beta_{2}$ are constants. Eq. (1) was fit to each of 7 years of data (Table 1) resulting in 7 estimates of $\beta_{0}, \beta_{1}$, and $\beta_{2}$. For each simulation year, a set of $\beta_{0}, \beta_{1}$, and $\beta_{2}$ values are generated from a multivariate normal distribution with variance/ ovariance based on the 7 estimates of the coefficients (Fig. 1). Temperatures below $4^{\circ} \mathrm{C}$ are set to $4^{\circ} \mathrm{C}$ because bay anchovy are generally not found in waters with temperatures $<4^{\circ} \mathrm{C}$ (Vouglitois et al. 1987).

Bay anchovy is a visual feeder and much of its feeding takes place during daylight hours (Vazquez 1989, Klebasko 1991). The fraction (DL) of the 24 h day considered to be daylight (Dalton 1987) is:

$$
D L=0.51+0.11 \cos [0.0172(d a y-173)]
$$

Spawning and immigration by females. Spawning females include those individuals born in the mesohaline model box plus a net immigration of individuals

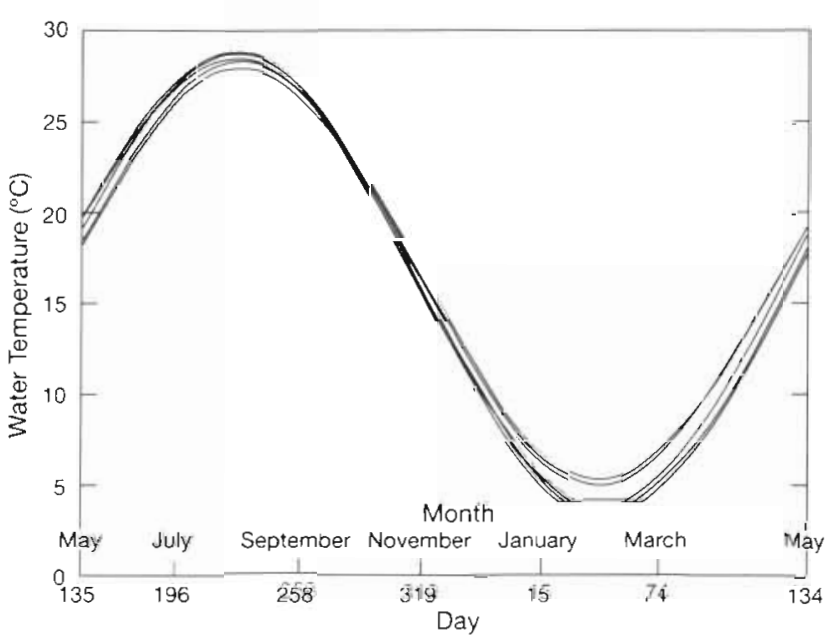

Fig. 1 Daily temperatures $\left(T,{ }^{\circ} \mathrm{C}\right)$ for 6 randomly selected years of the 50 yr simulations 
from elsewhere in Chesapeake Bay. Incorporating net immigration of spawners was required to achieve longterm population stability (persistence) with realistic early-life-stage growth and survival rates. The actual number of spawners in the mesohaline region of the Chesapeake Bay varies each year somewhat independently of the number of survivors from the previous year because bay anchovy migrate to the southern portion of the Bay (as well to coastal waters) in the winter, with some returning to the mesohaline mid-Bay to spawn the next year (Wang \& Houde 1995). Net immigration into the mesohaline model box each year is represented in 2 ways: as a multiplier of the number of spawners hatched in the model box or as a constant number entering. All added spawners were assumed to be $55 \mathrm{~mm}$ Age 1 individuals and are added in a 1:1 sex ratio. Multiplier immigration represents a situation in which conditions for anchovy vary similarly over the entire Chesapeake Bay. High numbers of survivors in the mesohaline model box would imply good conditions Bay-wide and thus a high number of immigrants the next year. Constant immigration assumes that survivorship in the mesohaline region is not related to survivorship in other regions of the Chesapeake Bay; the simplest assumption for constant immigration is a fixed number of annual immigrants. Multiplier and constant immigration levels were determined by calibration to result in a stable (persistent) population over time (see 'Results').

At the beginning of each spawning season (Day 135), each female $\geq 40 \mathrm{~mm}$ is assigned a start day and maximum number of batch spawns for the upcoming season. Start days are randomly assigned to females from a triangular distribution with minimum = Day 135, mode $=$ Day 150, and maximum = Day 160. Maximum number of batches are generated from a triangular distribution with minimum $=55$, mode $=60$, and maximum $=65$ (Table 1).

Females are evaluated each day during the spawning season to determine if they spawn. Fractional progress towards spawning a batch of eggs $\left(S_{\mathrm{p}}\right)$ is computed for each female on each day based upon the fraction of her assigned maximum number of batches that has been completed $(B T)$ :

$$
S_{p}= \begin{cases}0.25 & \text { if } B T \leq 0.06 \\ 18.75 B T-0.875 & \text { if } 0.06<B T \leq 0.01 \\ 1.0 & \text { if } 0.1<B T \leq 0.83 \\ -18.75 B T+16.56 & \text { if } 0.83<B T \leq 0.87 \\ 0.25 & \text { if } B T>0.87\end{cases}
$$

where $B T=$ number of batches completed divided by the maximum number of batches. On the day that the cumulative sum of $S_{p}$ for a female $\left(\sum S_{p}\right)$ exceeds 1 , she spawns, her cumulative progress towards egg release is reset to 0 , and the process begins again. Eq. (3) results in females spawning at an interval of about $4 \mathrm{~d}$ at the beginning and end of spawning season $(0.25$ is added to cumulative sum daily), with a peak interval of every day during the middle of the spawning season (1.0 is added to the cumulative sum daily). This frequency of spawning is similar to that observed for bay anchovy in the Chesapeake Bay (Luo \& Musick 1991). No progress towards spawning is allowed if simulated temperatures fall below $20^{\circ} \mathrm{C}$ and spawning is not permitted before Day 135 (May 15) or after Day 244 (September 1) (Luo \& Musick 1991, Zastrow et al. 1991).

The number of eggs released per batch $\left(N_{e}\right)$ is related to female weight ( $W_{f}, \mathrm{mg}$ dry wt) (Zastrow et al. 1991):

$$
N_{e}=304.8+2.02 W_{f}
$$

Females are allowed to feed, grow, and die during the spawning season. Daily fluctuations in female weight affect the number of eggs produced per spawning batch because weight on the day of egg release is used to determine fecundity.

Eggs and yolk-sac larvae: development and mortality. Each day's spawn of eggs is followed as a cohort through the egg and yolk-sac larval stages. Time to hatching of eggs and the development of yolk-sac larvae into feeding larvae depend upon temperature. Day of hatching and day of first feeding are determined by accumulating daily fractional development rates (Table 1) until the cumulative development exceeds 1.0. Daily fractional development towards hatching $\left(D V_{\mathrm{e}}\right)$ and first feeding $\left(D V_{y}\right)$ are computed each day as:

$$
\begin{aligned}
D V_{e} & =\frac{1}{8.38 \exp ^{-0.0856 T}} \\
D V_{y} & =\frac{1}{7.98-0.452 T+0.0075 T^{2}}
\end{aligned}
$$

where $T=$ daily water temperature.

The number of eggs and yolk-sac larvae in each daycohort is reduced daily by the fraction dying. Daily mortality is assumed to be $80 \% \mathrm{~d}^{-1}$ for eggs and $71 \%$ $\mathrm{d}^{-1}$ for yolk-sac larvae (Table 1 ). Because eggs and yolk-sac larvae develop rapidly $(<1$ to $2 \mathrm{~d}$ ), we adjust the fraction dying for fractional days of stage duration.

Larvae, juveniles, and adults: initial numbers, sizes, and development. At first feeding, all larvae are assigned the same initial weight and length $(0.009 \mathrm{mg}$ dry wt, Tucker 1989; which corresponds to $2.8 \mathrm{~mm} T L$ ). The dry weight (mg) of each larva, which varies day by day based upon simulated growth rate, is converted into length ( $L, \mathrm{~mm}$ ) daily (Table 1 ):

$$
L= \begin{cases}51.2 W^{0.594} & \text { if } W \leq 0.015 \mathrm{mg}(4.3 \mathrm{~mm}) \\ 12.4 W^{0.254} & \text { if } W>0.015 \mathrm{mg}\end{cases}
$$


Weight is partially uncoupled from length; length can only increase or remain unchanged. On days that individuals lose weight, their lengths are not changed. Following a weight loss, length is increased only after the individual has recovered to the weight predicted by the length-weight relationship. Larvae metamorphose into juveniles at $25 \mathrm{~mm}$; juveniles become adults at 40 mm (Houde \& Zastrow 1991).

Larvae, juveniles, and adults: growth. Daily growth in dry weight (mg) of an individual begining with first feeding is represented with a difference form $(1 \mathrm{~d}$ time step) of a bioenergetics equation:

$$
W_{t}=W_{t-1}+p C_{\max } A-R_{\mathrm{tot}}
$$

where $p=$ proportion of $C_{\max }$ realized; $C_{\max }=\operatorname{maxi}-$ mum dry-weight consumption rate $\left(\mathrm{mg} \mathrm{d}^{-1}\right) ; A=$ utilization efficiency; and $R_{\mathrm{tol}}=$ total dry-weight metabolic rate ( $\mathrm{mg} \mathrm{d}^{-1}$ ).

The proportion of $C_{\max }$ realized by an individual on a given day is:

$$
\begin{aligned}
p & =\frac{C_{\mathrm{r}}}{C_{\max }} \\
C_{\mathrm{r}} & =\sum_{i=1}^{n} B_{i} P W_{l}
\end{aligned}
$$

$C_{\mathrm{r}}=$ realized dry biomass $(\mathrm{mg})$ of prey consumed; $B_{i}=$ number of prey type $i$ eaten; and $P W_{1}=$ dry weight (mg) per individual of prey type $i$. When computing $C_{r}$, the summation over prey types $(i=1$ to $n$ in Eq. 10$)$ is performed in order of decreasing preference of prey types based on a prey selection algorithm. The prey selection algorithm and the computation of the number of each prey type consumed $\left(B_{1}\right)$ are described in detail in the section 'Computation of $p$ '.

Maximum consumption: Maximum consumption $\left(C_{\max }\right)$ depends upon an individual's weight $(W)$ and temperature $(T)$ (Table 1$)$ :

$$
C_{\max }= \begin{cases}47.37 W^{1.732} F(T) & \text { for } W<0.022 \mathrm{mg}(=4.7 \mathrm{~mm}) \\ 1.1019 W^{0.727} F(T) & \text { for } W \geq 0.022\end{cases}
$$

where $F(T)=$ temperature adjustment to $C_{\max }$ and $T_{0}$. $T_{m}$, and $\Theta=$ parameters of $F(T)$. Because bay anchovy may consume prey in amounts that exceed energetic $C_{\max }$ under very high prey densities, we allowed individuals to eat up to twice $C_{\max }$, while simultaneously decreasing utilization efficiency (as detailed below). The value of twice $C_{\max }$ was a reasonable guess, based on laboratory observations of consumption rates under very high prey densities (Houde \& Schekter 1980, 1981, Vazquez 1989).

The temperature-dependence of $C_{\max }[F(T)$ in Eq. $11]$ is initially a slowly rising function that reaches 1.0 at an optimal temperature, then rapidly drops to zero at a maximum temperature (Hewett \& Johnson 1987).
Three parameters are required to specify this function: the optimal temperature $T_{0}\left(28^{\circ} \mathrm{C}\right), \Theta(2.2)$ that mimics a $Q_{10}$ relationship for temperatures below optimal, and the maximum temperature $T_{\mathrm{m}}\left(37^{\circ} \mathrm{C}\right)$ (Table 1).

Utilization efficiency: Utilization efficiency $(A)$, the fraction of consumption available for growth and metabolism, varies as a function of bay anchovy weight and consumption.

$$
A= \begin{cases}\frac{\min \left(0.7 W^{0.15}, 0.7\right)}{0.83} & \text { if } \frac{C_{\mathrm{r}}}{C_{\max }}<0.83 \\ \frac{\min \left(0.7 W^{0.15}, 0.7\right)}{C_{\mathrm{r}} / C_{\max }} & \text { if } 0.83<\frac{C_{\mathrm{r}}}{C_{\max }}<2.0\end{cases}
$$

When consumption is at $C_{\max } A$ increases with weight from 0.35 for first feeders to 0.7 for fish greater than 1 $\mathrm{mg}(12.4 \mathrm{~mm})$. This value of $A$ is also increased under low consumption $\left(<0.83\right.$ of $\left.C_{\text {max }}\right)$ and reduced under high consumption ( $>0.83$ of $C_{\max }$ ) (Table 1 ).

Metabolism: Metabolic dry-weight losses $\left(R_{\mathrm{tot}} \mathrm{mg}\right.$ $\mathrm{d}^{-1}$ ) are determined as a routine component $\left(R_{\mathrm{r}}\right)$, dependent upon larval weight and temperature, and an active component, represented as a multiplier of routine metabolism for the period of feeding:

$$
R_{\mathrm{tot}}=\left[R_{\mathrm{r}}+(A C T-1) R_{\mathrm{r}} F F\right] \delta
$$

where $A C T=$ activity multiplier of routine metabolism; $F F=$ fraction of day in which metabolism is active $_{i}$ and $\delta=$ adjustment to metabolism under conditions of less-than-maintenance consumption. Routine metabolism is specified for a $24 \mathrm{~h}$ day; Eq. (13) is formulated so that routine metabolism applies only for the non-feeding period and active metabolism (which already includes routine metabolism) applies for the feeding period. The activity multiplier $(A C T)$ is assumed to be 2.0 for all life stages and all individuals are assumed to be actively feeding during daylight hours $(F F=D L)$.

Routine metabolism $\left(R_{r}\right)$ is determined as a function of larval weight and a $Q_{10}$ temperature relationship (Table 1):

$$
\begin{gathered}
R_{\mathrm{r}}= \begin{cases}0.146 W^{0.997} G(T) & \text { if } W<2.65 \mathrm{mg}(16 \mathrm{~mm}) \\
0.205 W^{0.653} G(T) & \text { if } W \geq 2.65 \mathrm{mg}\end{cases} \\
G(T)=\mathrm{e}^{\frac{\log _{\mathrm{e}}\left(Q_{40}\right)}{10}\left(T-T_{r}\right)}
\end{gathered}
$$

where $G(T)=$ temperature adjustment to $R_{\mathrm{r}} ; T_{\mathrm{r}}=$ temperature at which routine metabolism equals $R_{\mathrm{r}}\left(27^{\circ} \mathrm{C}\right)$; and $Q_{10}=$ parameter controlling rate at which $R_{\digamma}$ changes as a function of temperature (set to 2.2).

Adjustments for weight loss when $C_{r}$ is less than maintenance are needed to produce realistic rates of weight loss. The adjustment for larvae (in Eq. 13) is based upon data from starvation experiments, whereas the adjustment for juveniles and adults prohibits weight loss in excess of $2 \% \mathrm{BW} \mathrm{d}^{-1} . \delta$ operates when 
values of $p$ are between 0 and $p_{m c}$, the value of $p$ that results in maintenance consumption and zero growth $\left[p_{\mathrm{mc}}=R_{\mathrm{tot}} /\left(C_{\max } A\right)\right] . \delta$ is computed as:

$$
\delta=\left\{\begin{array}{cl}
1 & \text { if } W_{t+1} \geq W_{l} \\
\frac{5 R_{\mathrm{tot}}-0.35 W_{t}}{5 R_{\mathrm{tot}} p_{m c}} p+\frac{0.35 W_{t}}{5 R_{\mathrm{tot}}} & \text { if } W_{t+1}<W_{t}
\end{array}\right.
$$

$\delta$ reduces larval weight loss, such that when $\mathrm{p}=0,35 \%$ of body weight is lost after $5 \mathrm{~d}$; we assume that bay anchovy larvae will die from starvation if they lose $35 \%$ of their current weight (Table 1). We further assume a linear decrease in metabolic rate between maintenance consumption $\left(p_{\mathrm{mc}}\right)$ and zero consumption $(p=0)$.
Computation of $p$ : The value of $p$ is based upon random encounters of feeding individuals with multiple zooplankton prey types. The overall logic for computing the fraction of maximum consumption realized by an individual each day $(p)$ is shown in Fig. 2. Determination of $p$ involves realized consumption $\left(C_{r}\right)$, which is the sum of the number of each prey type eaten $\left(B_{1}\right.$ in Eq. 10) multiplied by prey weight. Number eaten $\left(B_{i}\right)$ is generated for each prey type $i$ from a binomial distribution and depends on the number of encounters $\left(E_{l}\right)$, the fraction of those that are encountered which are attacked $\left(P_{\mathrm{A}}\right)$, and the probability of capture $\left(C A P_{i}\right)$. The summation over prey types of $B_{i}$ in Eq. (10) depends on prey selection by the fish.

\section{Computation of $p$}

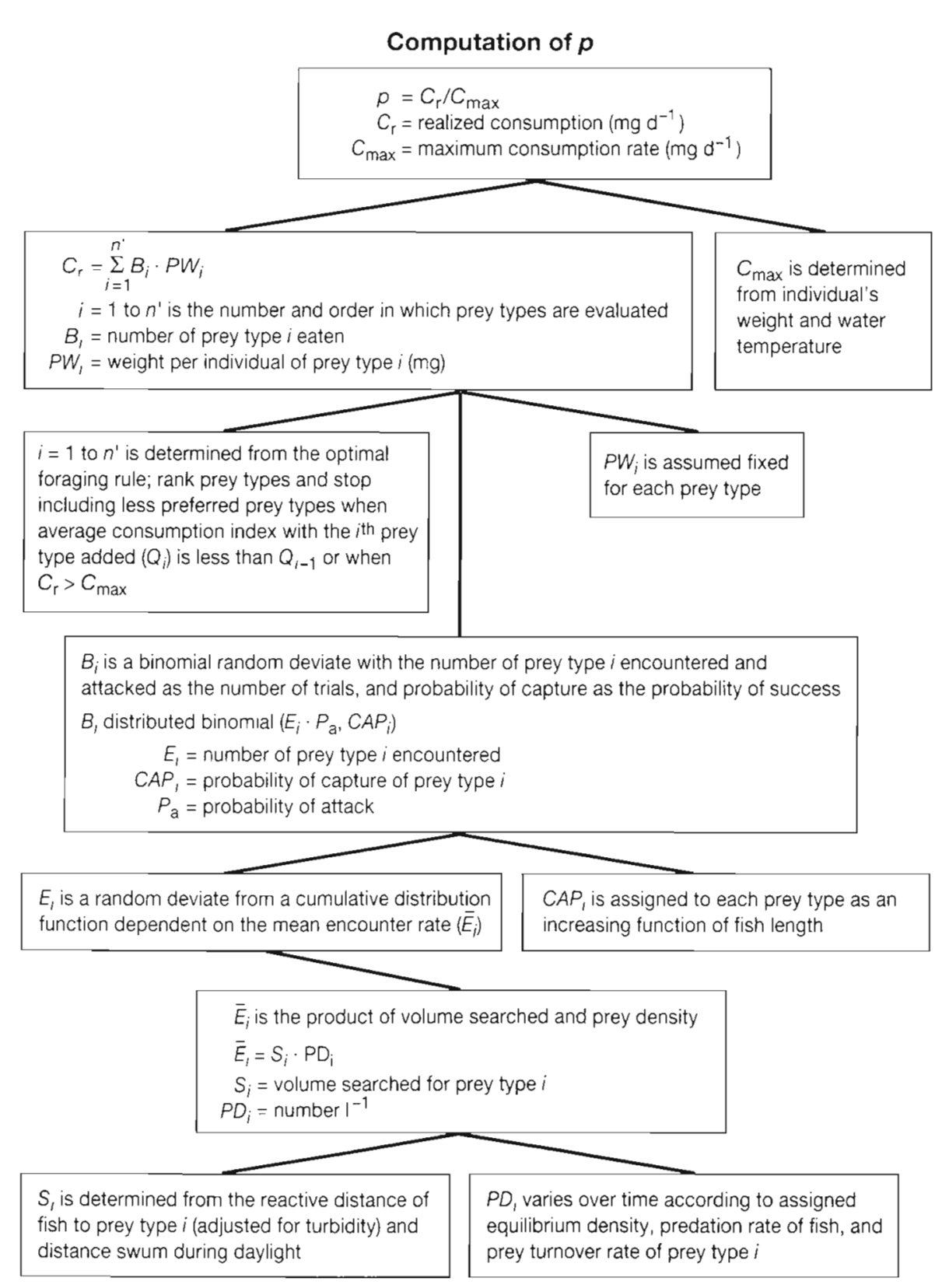

Fig. 2. Logic for computation of the fraction of maximum consumption (p) realized by a feeding individual on each day. All weights are dry weights 
Four zooplankton prey types are represented: tintinnids and rotifers, nauplii, copepodites, and adult copepods, which account for most prey items in diets of bay anchovy (Houde \& Zastrow 1991, Klebasko 1991). Each zooplankton type is defined by a mean dry weight $\left(P W_{i}\right.$, $\mathrm{mg})$ and length $\left(P L_{i}, \mathrm{~mm}\right)$ per individual, maximum turnover rate $\left(\mathrm{d}^{-}\right)$(Table 2 ), and equilibrium density $\left(P D^{*}\right.$, no. $\left.\mathrm{l}^{-1}\right)$.

The number of each zooplankton prey type encountered by an individual anchovy $\left(E_{i}\right)$ is determined stochastically and depends upon mean encounter rate $\left(E_{j}^{M}\right)$, the product of search volume $(S$, liters) and prey density $(P D$. no. $1^{-1}$ ):

$$
E_{i}^{M}=S_{1} P D_{1}
$$

The realized number of cncountcrs of cach prey typo $\left(E_{i}\right)$ is generated as a random deviate from a cumulative distribution function $(C D F)$ to simulate prey patchiness (Fig. 3). Encounters are generated by selecting a random number between 0 and 1 , and multiplying the mean encounter rate of the zooplankton type $\left(E_{1}^{M}\right)$ by the corresponding multiplier on the ordinate of the CDF (Table 1).

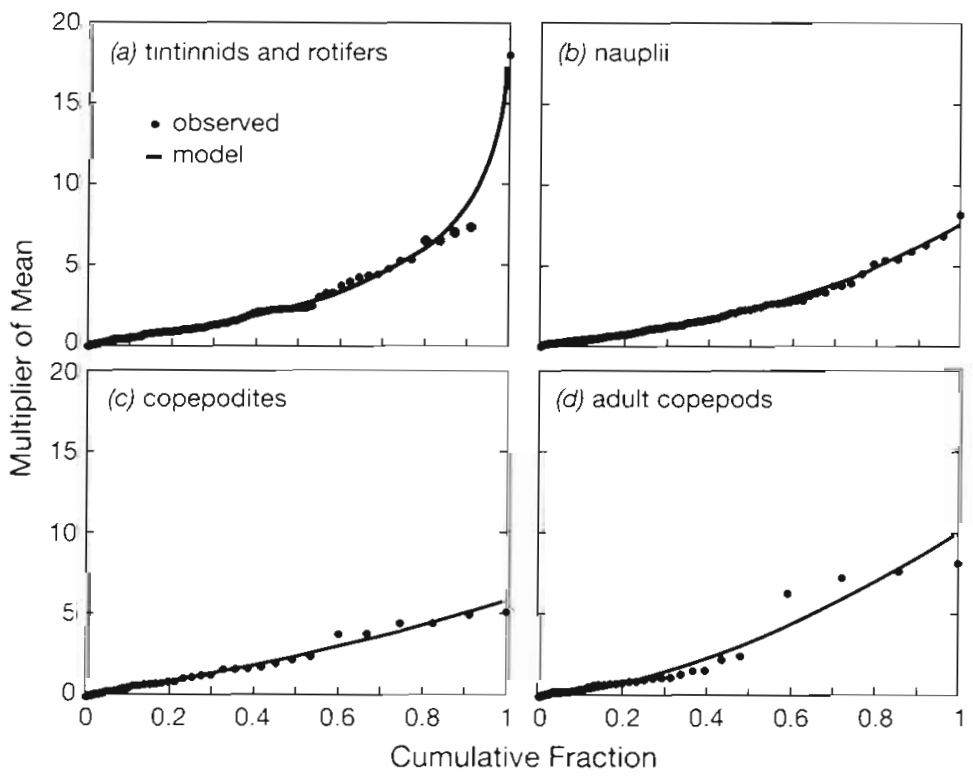

Fig. 3. Cumulative distribution functions $(C D F)$ of tintinnids and rotifers, nauplii, copepodites and adult copepods relating the cumulative fraction of field samples with prey concentrations (expressed as a multiplier of the mean) less than some value. Encounters of anchovy with prey are generated by selecting a random number between 0 and 1 and multiplying the mean encounter rate by the corresponding multiplier on the ordinate of the $C D F$. Field data for tintinnid/ratifer and nauplis ( $\mathrm{S}$. Brownlee, The Academy of Natural Sciences, Benedict, MD, USA, pers. comm.) and for copepodite and adult copepods (Olson 1987) consisted of monthly samples at stations in the mesohaline Chesapeake Bay (see Table 1)
Scarch volume $\left\{S_{1}\right\}$ for an individual anchovy feeding on zooplankton type $i$ is computed as one-half the volume of a cylinder with radius equal to reactive distance, and height equal to distance swum during daylight hours:

$$
S_{i}=\frac{\pi}{2}\left(R D_{i} F_{R D}\right)^{2}\left[a_{S S} L F F \frac{3600 \mathrm{~s}}{\text { day }} 24\right] \frac{10^{-6} \mathrm{l}}{\mathrm{mm}^{3}}
$$

where $F_{R D}=$ a decimal fraction that reduces reactive distance due to turbidity; $a_{\mathrm{ss}}=$ fish swimming speed ( 1 body length $\mathrm{s}^{-1}$ ); and $F F=$ fraction of the day spent feeding (assumed to be daylight hours, $F F=D L$ ). The one-half cylinder volume assumption accounts for a clupeoid not perceiving prey below the horizontal axis of the body (Rosenthal \& Hempel 1970).

Reactive distance $(R D)$ is based on angle of acuity of the feeding individual ( $\alpha$, degrees) and the height (length, $P L_{1}$ ) of the prey:

$$
R D_{j}=\frac{P L_{1}}{2 \tan \left(\frac{\alpha}{2}\right)}
$$

$\alpha$ decreases with increasing length of the fish (Breck \& Gitter 1983):

$$
\alpha=0.0167 \mathrm{e}^{514-24 \log _{\mathrm{e}}(L)+0.229 \log _{\mathrm{e}}(L)^{2}}
$$

Thus, larger fish have larger RDs for a given size prey; and for a given fish, larger (longer) prey are seen at a farther distance than smaller (shorter) prey (Table 1).

Reactive distances predicted by Eqs. (19) \& (20) are reduced proportionally in the model by the turbidity factor $F_{R D}$ because turbidity has an increasing effect with increasing $R D$ (Vinyard \& O'Brien 1976, Chesney 1989)

$$
F_{R D}= \begin{cases}0.8-0.025 R D & \text { if } R D<15 \mathrm{~mm} \\ 0.4 & \text { if } R D \geq 15 \mathrm{~mm}\end{cases}
$$


Thus, RDs are reduced by $80 \%$ (for a $R D$ of $1 \mathrm{~mm}$ ) to $40 \%$ (for $R D$ s greater than $15 \mathrm{~mm}$ ) of the values predicted by Eqs. (19) \& (20) (Table 1). The increasing effect of turbidity results in larger $R D$ s being reduced by greater absolute amounts, although by lower percentages. Several authors have reported that moderate turbidity levels can have little effect on, or even increase, larval feeding because of enhanced visual contrast of prey items (Boehlert \& Morgan 1985; see Chesney 1989). Most studies demonstrating reduced feeding under moderate to high turbidity conditions involve post-larval fish.

The proportion of prey encountered that are subsequently ingested is represented by the product of probabilities of capture and attack, and a prey selection algorithm. Capture probabilities are specified for each zooplankton type in relation to anchovy length:

$$
C A P_{i}= \begin{cases}0.114 L+0.057 & \text { for tintinnids and rotifers } \\ 0.115 L+0.23 & \text { for nauplii } \\ 0.115 L+0.46 & \text { for copepodites } \\ 0.140 L+1.95 & \text { for adult copepods }\end{cases}
$$

Capture probabilities given by Eq. (22) increase until they are truncated at 0.9 (Fig. 4, Table 1). Differences among capture probabilities are greatest for small larvae.

Bay anchovy do not attack every prey item encountered. The realized number of encounters $\left(E_{l}\right)$ is multiplied by an attack probability to obtain the realized number of prey type encountered and attacked. To permit great flexibility in its functional form, we represent the probability of attack as a piecewise linear function of anchovy length (Fig. 5). Probabilities of attack were determined by calibration (trial and error simulation) to get realistic bay anchovy growth rates.

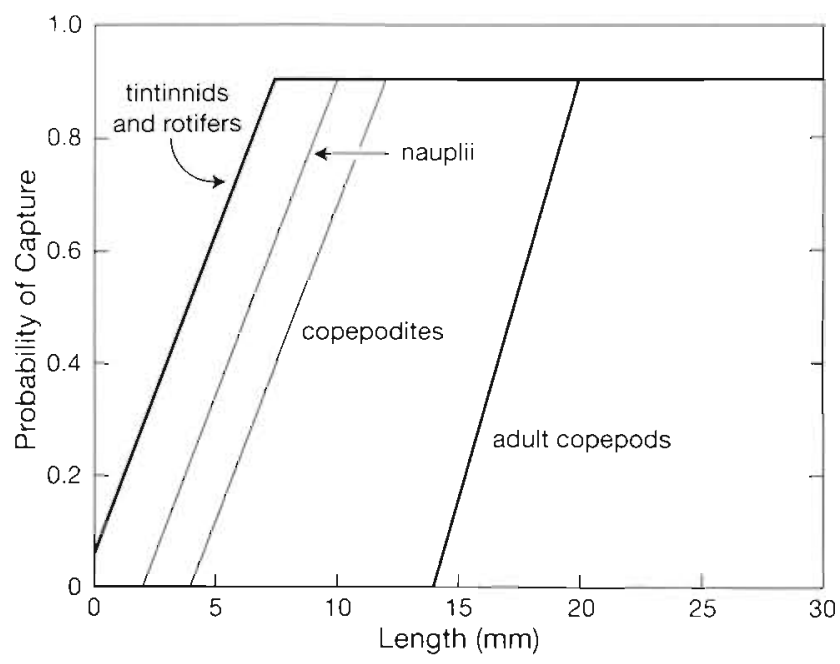

Fig. 4. Anchoa mitichilli. Capture probabilities of larval bay anchovy consuming zooplankton prey.

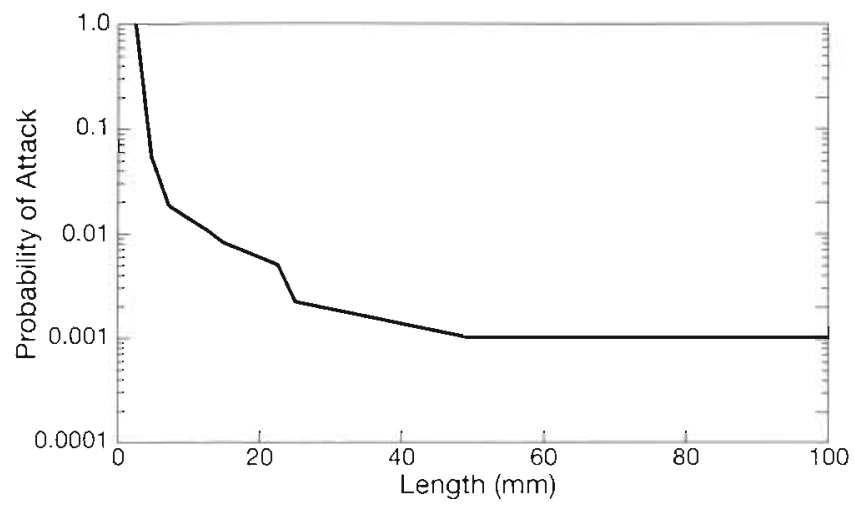

Fig. 5. Anchoa mitichilli. Probability of attack by bay anchovy consuming zooplankton prey. The probability of attack value for an anchovy of a given length is used for all 4 zooplankton prey types

Fish tend to consume 'more preferred' prey when it is available and switch to 'less preferred' prey types when more preferred types are rare. We represent this preference in the model using general results from foraging theory (Krebs 1978, Hughes 1980, Hart 1986). To determine which prey types will be eaten by an individual anchovy on a given day, the prey are first ranked in descending order of preference based upon expected energy gain $\left(P W_{i} \times C A P_{i}\right)$. Prey are then added to the diet (the summation over $n$ prey types in Eq. 10) in decreasing order of preference. Prey types are included in the diet until the consumption rate index with the added prey type $i\left(Q_{i}, \mathrm{mg} \mathrm{s}^{-1}\right)$ decreases, compared to the index with prey types 1 through $i-1$ $\left(Q_{i-1}\right)_{\text {; }}$ the index is

$$
Q_{i}=\frac{\sum_{k=1}^{i} P W_{k} B_{k} T_{D}}{1+\sum_{k=1}^{i} B_{k} T_{D}}
$$

where $B_{k}=$ number of prey type $k$ eaten; $P W_{k}=$ dry weight $(\mathrm{mg})$ per individual of prey type $k_{i}$ and $T_{D}=$ the inverse of the approximate number of seconds during daylight hours $\left(2.3 \times 10^{-5}\right)$. Individuals are assumed to consume all successfully captured individuals of each prey type, starting from the most preferred, until all eligible prey types have been consumed or until consumption exceeds twice maximum consumption.

Temporal dynamics of prey: Densities of each zooplankton prey type $i\left(P D_{i, t}\right.$, no. $\left.1^{-1}\right)$ are updated daily based upon a logistic equation with a loss term for the number of prey consumed by bay anchovy $\left(E A T_{1,1}\right)$.

$P D_{1, t+1}=P D_{i, t}+2.0 P D_{1, t}\left(1.0-\frac{P D_{1, t}}{P D_{j, t}^{*}}\right) P T_{1}-E A T_{1, t}$

where $P D_{i, l}^{*}=$ equilibrium density or the maximum density (no. $\mathrm{I}^{-1}$ ) allowed in simulations; $P T_{i}=$ maximum 

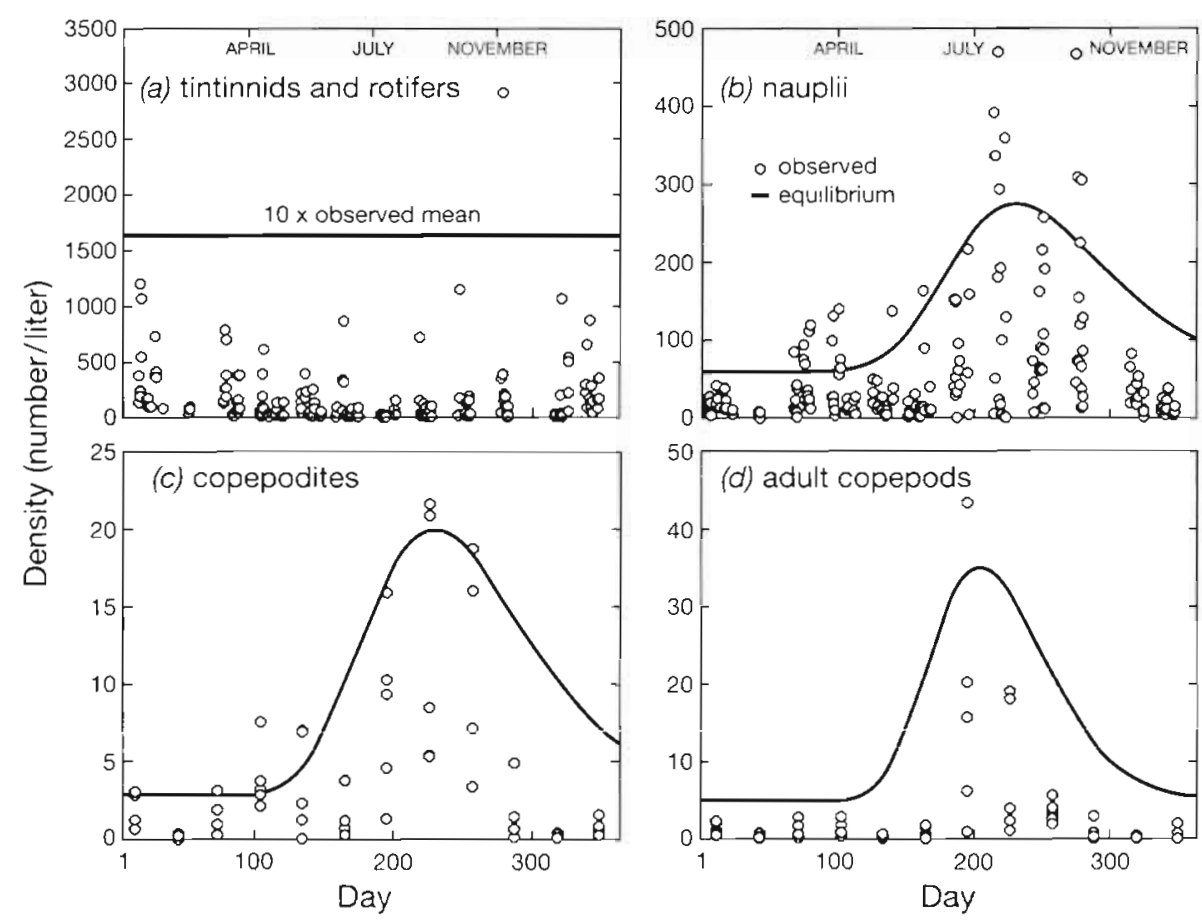

Fig. 6. Field data and assumed equilibrium densities of zooplankton prey. Equilibrium densities of tintinnids and rotifers are assumed constant; equilibrium densities of nauplii, copepodites and aduil copepudis are assumed time-dependent. Field data are the same as those used to construct cumulative distribution functions (see Fig. 3. Table 1) turnover rate $\left(\mathrm{d}^{-1}\right)_{i}$ and $E A T_{i, \ell}=$ total consumption of prey type $i$ (no. $\mathrm{l}^{-1}$ ) by anchovy. The multiplier 2 in Eq. (24) results in the specified maximum turnover rates being realized when prey densities are at one-half their equilibrium densities. Without the multiplier of 2 , maximum turnover rates $\left(P T_{i}\right)$ are realized when prey densities approach zero.

Equilibrium densities for tintinnids and rotifers are assumed to be constant during the period when larvae are present, and related to day of the year for nauplii, copepodites, and adult copepods (Fig. 6, Table 1). Functions relating equilibrium densities to day of year were fit to the upper reported densities to account for predator effects on prey densities. Reported zooplankton densities already reflect the consumption rate of zooplankton by predators. In lieu of detailed information about the zooplankton consumption rates of the total predator community, we crudely adjust for predator effects by fitting the functions to the upper reported values. We assume that the total predator effect roughly reduces nauplii, copepodites, and adult copepod densities by about one-half, as fitted equilibrium densities are about twice the average densities. Maximum turnover rates $\left(P T_{1}\right)$ are assumed constant for each zooplankton prey type (Tables $1 \& 2$ ). $E A T_{j, t}$ is computed as:

$$
E A T_{i, t}=\sum_{j=1}^{N} \frac{B_{j, 1} n_{1}}{V O L \cdot 10^{3}}
$$

where $B_{j, i}=$ total no. of prey type $i$ eaten by the $j^{\text {th }}$ individual; $N=$ no. of model individuals; $n_{j}=$ number of population individuals represented by the $j^{\text {th }}$ model individual (see 'Methods: Numerical considerations'); and $V O L=$ volume $\left(\mathrm{m}^{3}\right)$ of the spatial compartment

Larvae, juveniles, and adults: mortality. Mortality rates are dependent upon weight and length or lifestage. Weight-dependent mortality is interpreted as starvation. Mortality dependent upon length or life stage is estimated from field data and therefore primarily represents predation and/or emigration losses.

Individuals die in the simulations if their weight declines below a minimum weight $\left(W_{\min }\right)$ defined as a fraction $\left(K_{\min }\right)$ of their weight based upon their length $\left(W_{L}\right)$ :

$$
W_{\min }=K_{\min } W_{L}
$$

where $W_{L}=$ predicted weight from length (Eq. 7). The fraction of expected weight that induces starvation $\left(K_{\mathrm{min}}\right)$ is 0.65 for larvae (35\% weight loss) and 0.5 for juveniles and adults (Table 1).

Length-based mortality for larvae $\left(Z, \mathrm{~d}^{-1}\right)$ is derived by combining a relationship between mortality rate $\left(\mathrm{mm}^{-1}\right)$ and length (Loos \& Perry 1991) with an assumed $0.7 \mathrm{~mm} \mathrm{~d}^{-1}$ growth rate (Fig. 7):

$$
Z=\left(\frac{2.8}{L^{1.332}}\right) \mathrm{e}^{-0.0093 L}
$$

Mortality is fixed at $Z=0.032 \mathrm{~d}^{-1}$ for juveniles, $Z=$ $0.0095 \mathrm{~d}^{-1}$ for YOY adults, and $Z=0.005 \mathrm{~d}^{-1}$ for Age 1 and older adults (Table 1). Probability of dying $\left(1-\mathrm{e}^{-z}\right)$ is evaluated daily based upon each individual's length and age or life stage. If a generated random number from a uniform distribution between 0 and 1 is less than the probability of dying, the individual dies. 
Initial conditions. Model simulations are initiated with 250 females of $54 \mathrm{~mm}$ length ( $327 \mathrm{mg}$ dry wt). All 250 individuals die by Year 3 of the simulation; by Year 4 all spawners are model-generated individuals. At the beginning of each year of the 50 yr simulations, a new set of $365 \mathrm{~d}$ of daily temperatures is generated and the initial densities of each zooplankton group are reset to equilibrium densities.

Numerical considerations. Two numerical procedures are used to increase execution speed, reduce the computer memory requirements, and ensure accuracy of the model under high mortality rate conditions. First, a constant number of 3000 model individuals (with each representing some number of identical population individuals) is simulated using a resampling algorithm (Rose et al. 1993). The resampling algorithm consists of replacing the attributes of model individuals that die during one day with the attributes of randomly selected surviving individuals and adjusting the population value of the donor individual to reflect mortality. Second, on May 15 of each year, the number of surviving model individuals are rescaled to keep the number of population individuals represented from becoming too small. The number of YOY, Age 1, and Age 2+ model individuals are reset to the actual number of population individuals and their population worth set to 1 . The attributes of the new model individuals are determined by randomly sampling from the model individuals. Model predictions with and without these numerical procedures are indistinguishable.

\section{METHODS: DESIGN AND ANALYSIS OF SIMULATIONS}

Two 50 yr baseline simulations were performed corresponding to multiplier and constant immigration assumptions. Results from Years 4 to 50 of each simulation were analyzed; the first 3 years were not included to eliminate effects of initial conditions. Recruitment was defined as the number of YOY anchovy that became adults (>40 $\mathrm{mm}$ ) by May 15 .

For the baseline simulations, the magnitude of net immigration into the box necessary for population stability over time was determined. The multiplier of spawners or the constant number added was progressively increased until simulated total population numbers remained stable (persistent without any obvious trend) for the 50 years.

For both the multiplier and constant immigration simulations, within-year and multi-year model predictions were analyzed and, when possible, compared to observed values to check model realism. The data sources for many of the observed values are described in Table 3. Within-year dynamics were examined in 2

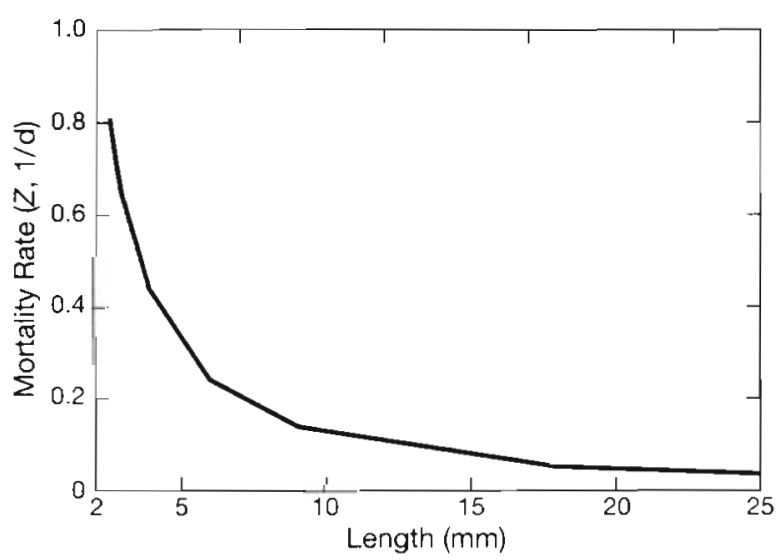

Fig. 7. Anchoa mitichilli. Equation relating mortality rate to larval bay anchovy length. The equation (Eq. 27) is derived by combining a mortality per mm related to length relationship (Loos \& Perry 1991) and an assumed $0.7 \mathrm{~mm} \mathrm{~d}^{-1}$ growth rate

ways. We report life-stage-specific durations, mortality rates, growth rates, and numbers entering, and diets, averaged over the 47 years, for the multiplier immigration simulation. Life stage durations and rates and diets based on the constant immigration baseline simulation were practically identical. Values of duration, survival, and growth are shown for the YOY juvenile and adult stages combined; the YOY juvenile stage, as defined in this paper, was $<20 \mathrm{~d}$ in duration. We also examine within-year dynamics (anchovy densities and zooplankton dynamics) using 10 consecutive years (19 to 28 ) that illustrated the range of dynamics exhibited by baseline simulations. Years 19 to 28 include the lowest (Year 26) and highest (Year 21) recruitment for the multiplier immigration simulation, and the lowest (Year 26) and fourth highest (Year 25) recruitment for the constant immigration simulation. Whenever possible, within-year model predictions were compared to observed values.

Multi-year dynamics of the baseline simulations were examined for population variation over time, and relationships among growth, survival, recruitment, egg production, temperature, and anchovy density. Relationships were determined using linear regression of annual average values of all variables. Analyses involving growth and survival rates were performed separately for the larval, YOY juvenile, and YOY adult life stages. Growth and survival rates were regressed on recruitment and the numbers entering the life stage $_{i}$ survival rate was also regressed on growth rate. It is possible that growth could appear to be densitydependent due to temperature effects. Warmer temperatures could lead to both higher numbers entering and faster growth, without any influence of anchovy consumption on zooplankton densities. To address this possibility, we first computed Pearson correlation coefficients between monthly average temperatures and 
Table 3. Anchoa mitichilli. Sources for some of the observed data used to compare with predictions from the individual-based bay anchovy model

\begin{tabular}{|c|c|c|}
\hline Variable & Summary of values & Source \\
\hline $\begin{array}{l}\text { Egg and larval } \\
\text { peak densities }\end{array}$ & $\begin{array}{l}100-450 \text { eggs } \mathrm{m}^{-2} \\
-40-80 \text { larvae } \mathrm{m}^{-3}\end{array}$ & $\begin{array}{l}\text { Peak densities (based upon means over stations or over multiple samples at a } \\
\text { station) adjusted for net extrusion (Houde \& Lovdal 1984) ranged from } 100 \text { to } \\
250 \text { eggs } \mathrm{m}^{-3} \text { and } 2 \text { to } 40 \text { larvae } \mathrm{m}^{-3} \text { during the late spring and summer (Bis- } \\
\text { cayne Bay, FL, Houde \& Lovdal } 1984 \text {; Great South Bay, } \mathrm{NY} \text {, Castro \& Cowen } \\
\text { 1991). Dorsey (1993) reported an average egg density of } 4270 \mathrm{~m}^{-3} \text { (peak daily } \\
\text { mean of } 1177.1 \mathrm{~m}^{-3} \text { ) during } 12 \mathrm{~d} \text { in July } 1991 \text { at several locations in Chesa- } \\
\text { peake Bay. MacGregor \& Houde (1996) reported daily mean densities of } 24.0 \\
\text { to } 107.2 \text { eggs } \mathrm{m}^{-3} \text { and } 3.3 \text { to } 19.7 \text { larvae } \mathrm{m}^{-3} \text { near the mouth of the Patuxent } \\
\text { River sub-estuary. Peak densities based upon cruise and station means or } \\
\text { monthly means were } 101-232 \text { eggs } \mathrm{m}^{-3} \text { and } 11-76 \mathrm{larvae}^{3} \text {, and for single } \\
\text { collections, were } 430 \text { eggs } \mathrm{m}^{-3} \text { and } 90-164 \text { larvae } \mathrm{m}^{-3} \text { from various studies in } \\
\text { the Chesapeake Bay and the Patuxent River (Houde \& Zastrow 1991) }\end{array}$ \\
\hline $\begin{array}{l}\text { Juvenile and adult } \\
\text { densities from } \\
\text { August to October }\end{array}$ & $\sim 1-5 \mathrm{~m}^{-3}$ & $\begin{array}{l}\text { Reported densities of bay anchovy during October in the Calvert Cliffs } \\
\text { region of Chesapeake Bay averaged } 0.65 \text { in } 1990 \text { and } 0.79 \mathrm{~m}^{-3} \text { in } 1991 \text { based } \\
\text { upon trawl surveys; densities of } 1.0-2.0 \mathrm{~m}^{-3} \text { were observed at various depths } \\
\text { during August and October (Wang } 1992 \text { ). Wang \& Honde (1995) concluded } \\
\text { that densities in August and October based upon acoustic estimates were } \\
2.3-4.4 \text { times higher than corresponding trawl estimates }\end{array}$ \\
\hline $\begin{array}{l}\text { Mortality rates } \\
\text { involving larvae }\end{array}$ & $\begin{array}{l}0.5-0.75 \mathrm{~d}^{-1} \text { for egg } \\
\text { to } \sim 11 \mathrm{~mm} \\
\sim 0.35 \mathrm{~d}^{-1} \text { for first } \\
\text { feeding to } \sim 1.1 \mathrm{~mm} \\
0.08-0.18 \mathrm{~d}^{-1} \text { for } \\
\text { larval stage }\end{array}$ & $\begin{array}{l}\text { Reported mortality rates of daily cohorts, based upon daily ages derived } \\
\text { from otolith analysis, were about } 0.25 \text { to } 1.25 \mathrm{~d}^{-1} \text { (with most values between } \\
0.50 \text { and } 0.75 \mathrm{~d}^{-1} \text { ) for eggs through about } 11 \mathrm{~mm} \text { (Leak \& Houde 1987), and } \\
0.20 \text { to } 0.48 \mathrm{~d}^{-1} \text { for first feeding to } 12 \mathrm{~mm} \text { (Castro \& Cowen 1991). Rilling } \\
\text { (1996) reported mortality rates ranging from } 0.26 \text { to } 0.44 \mathrm{~d}^{-1} \text { for small larvae } \\
\text { during June and July in Chesapeake Bay. Larval mortality rates of } 0.18 \mathrm{~d}^{-1} \\
\text { (Houde } 1987 \text { ) and } 0.084 \mathrm{~d}^{-1} \text { (PSE\&G 1984), calculated based upon catch- } \\
\text { curve analysis, have been reported }\end{array}$ \\
\hline $\begin{array}{l}\text { Early larval growth } \\
\text { rates }\end{array}$ & $\sim 0.5-0.75 \mathrm{~mm} \mathrm{~d}^{-1}$ & $\begin{array}{l}\text { Reported growth. rates from hatch to about } 20 \text { d post hatch (10 to } 15 \mathrm{~mm} \text { ) vary } \\
\text { between } 0.45 \text { and } 0.62 \mathrm{~mm} \mathrm{~d}^{-1} \text { based upon in situ Chesapeake Bay enclosure } \\
\text { experiments (Cowan \& Houde 1990) and otolith-age analysis of larvae from } \\
\text { Biscayne Bay, FL (Leak \& Houde 1987) and Great South Bay, NY (Castro \& } \\
\text { Cowen } 1991 \text { ). A recent study in Chesapeake Bay suggested early larval growth } \\
\text { rates of } 0.5 \text { to } 0.75 \mathrm{~mm} \mathrm{~d}^{-1} \text {; rates were lower in June than in July (Rilling 1996) }\end{array}$ \\
\hline Mean lengths at age & $\begin{array}{l}52 \mathrm{~mm} \text { at Age } 1 \\
66 \mathrm{~mm} \text { at Age } 2 \\
80 \mathrm{~mm} \text { at Age } 3\end{array}$ & $\begin{array}{l}\text { Observed mean lengths of anchovy recruits during April of } 1.990 \text { and } 1991 \\
\text { in the Calvert Cliffs area averaged about } 52.0 \mathrm{~mm} \text {, with individuals ranging } \\
\text { from 32-65 mm (Wang 1992). Typical lengths of Age } 2 \text { and Age } 3 \text { (at annulus } \\
\text { formation-May 15) anchovy from. Von Bertalanffy curves fit to } 4 \text { years of } \\
\text { data were } 63.6-70.0 \mathrm{~mm} \text { and } 78.3-86.4 \mathrm{~mm} \text { (Wang 1992) }\end{array}$ \\
\hline $\begin{array}{l}\text { Bay anchovy effect } \\
\text { upon zooplankton } \\
\text { densities }\end{array}$ & $\begin{array}{l}\text { Bay anchovy } \\
\text { consumption can } \\
\text { significantly reduce } \\
\text { zooplankton densities }\end{array}$ & $\begin{array}{l}\text { Klebasko (1991) estimated that the juvenile and adult anchovy population } \\
\text { could consume } 23-41 \% \text { of the daily production of Acartia during October in } \\
\text { the Chesapeake Bay. Leak (1984) calculated that bay anchovy larvae in } \\
\text { Biscayne Bay, FL, could consume less than } 2 \% \text { daily of the standing stock of } \\
\text { copepod nauplii and copepodites (zooplankton less than } 100 \mu \mathrm{m} \text { wide) but } \\
\text { from } 1.4 \text { to } 14.7 \% \text { of the standing stock of copepods greater than } 100 \mu \mathrm{m} \text { in } \\
\text { width in the late summer and fall. Luo \& Brandt (1993) modeled bay anchovy } \\
\text { consumption rate of zooplankton at about } 1 / 3 \text { the zooplankton production rate } \\
\text { during August to September Wang \& Houde (1995) suggested that bay } \\
\text { anchovy could potentially consume almost } 50 \% \text { of the zooplankton standing } \\
\text { stock in August to October in areas of Chesapeake Bay. However, all of these } \\
\text { field studies were based upon simple static calculations applied to temporal } \\
\text { and spatial snapshots of data; their conclusions should be viewed with caution }\end{array}$ \\
\hline $\begin{array}{l}\text { Anchovy consump- } \\
\text { tion rates }\end{array}$ & 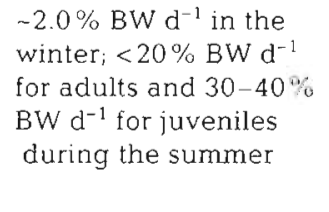 & 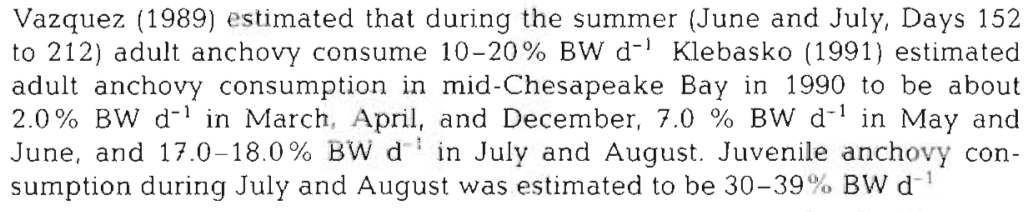 \\
\hline $\begin{array}{l}\text { Population age } \\
\text { structure }\end{array}$ & $\begin{array}{l}\text { Age } 0+\text { comprise } \\
80-85 \%\end{array}$ & $\begin{array}{l}\text { Wang (1992) reported that in Spring samples taken in the Maryland portion } \\
\text { of Chesapeake Bay, Age 0+ individuals (i.e. approaching Age 1) comprised } \\
80.5 \% \text { of adult anchovies in } 1990 \text { and } 85.9 \% \text { in } 1991\end{array}$ \\
\hline
\end{tabular}


Fig. 8. Anchoa mitichilli. Predicted total population and recruits on May 15 of each year for the multiplier and constant immigration baseline simulations
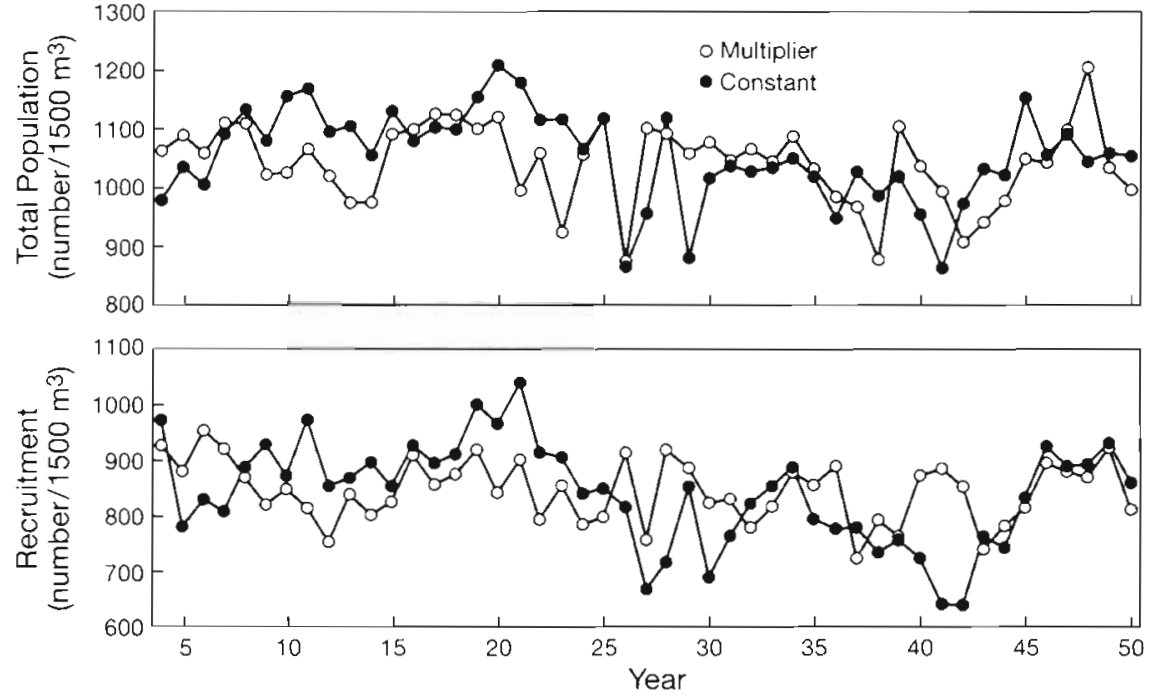

growth rates for each life stage. We then regressed growth rates on the numbers entering and the most significant monthly temperature. We report the $R$ value for the simple regression model involving numbers entering only, and the partial $\mathrm{R}$ value attributed to the numbers entering variable for the regression that included numbers entering and monthly temperature

Regression analysis was also used to quantify density-dependent egg production and first-year survival. We analyzed the multiplier immigration simulation using regression to determine relationships among annual values of adult bay anchovy mean lengths, spawner number, total egg production, and eggs produced per spawner. We also compare first-year survival between years of high and low egg production.

All reported correlation coefficients are Pearson correlation based on linear regression, which assumes a linear relationship between the response and explanatory variable. Results were confirmed by repeating the analyses using Spearman rank correlation, which measures the strength of monotonic, not necessarily linear, relationships

Table 4. Anchoa mitichilli. Stage-specific durations, mortality rates, growth rates, and numbers entering, averaged over the 47 years of the multipier immigration baseline simulation

\begin{tabular}{|lccccc|}
\hline Stage & $\begin{array}{c}\text { Duration } \\
(\mathrm{d})\end{array}$ & $\begin{array}{c}\text { Mortality } \\
\left(\mathrm{d}^{-1}\right)\end{array}$ & $\begin{array}{c}\text { Survival } \\
(\%)\end{array}$ & $\begin{array}{c}\text { No. } \\
\text { entering }\end{array}$ & $\begin{array}{c}\text { Growth } \\
\left(\mathrm{mm} \mathrm{d}^{-1}\right)\end{array}$ \\
\hline Egg & 0.85 & 1.62 & 25.0 & 56734 & - \\
Yolk-sac larva & 1.27 & 1.22 & 21.0 & 14361 & - \\
Larva & 33.0 & 0.15 & 0.7 & 3082 & 0.70 \\
$\quad$ Early (<10 mm) & 11.4 & 0.31 & 2.9 & 3082 & 0.69 \\
Late (>10 mm) & 21.6 & 0.067 & 23.0 & 89.5 & 0.72 \\
YOY juvenile and adult & 264.5 & 0.012 & 3.8 & 20.8 & 0.092 \\
\hline
\end{tabular}

\section{RESULTS}

\section{Baseline simulation}

Net immigration

Population extinction in the modeled box was predicted when simulated life-stage-specific mortality and growth rates agreed with observed values. Invoking net immigration by adding 0.7 times the number of model spawners each year ( 420 to 906 , mean of 622) or adding 622 spawners every year resulted in a stable population over time (Fig. 8). On average, spawners hatched in the mesohaline model box comprised $56 \%$ of the total spawners each year.

\section{Within year dynamics}

Model-predicted densities by life stage were reasonable. Ranges of peak densities for Years 19 to 28 were 161 to 221 eggs $\mathrm{m}^{-3}, 69$ to 104 larvae $\mathrm{m}^{-3}$, and 4.5 to 8.4 juveniles and adults $\mathrm{m}^{-3}$ for multiplier immigration, and 180 to 233 eggs $\mathrm{m}^{-3}, 78$ to 100 larvae $\mathrm{m}^{-3}$, and 5.6 to 8.1 juveniles and adults $\mathrm{m}^{-3}$ for constant immigration (Fig. 9). Reported peak densities in the mesohaline Chesapake Bay are 100 to 450 eggs $\mathrm{m}^{-3}$ and -40 to 80 larvae $\mathrm{m}^{-3}$ (Table 3). Model predictions of total adults (mostly new recruits) on October 15 (Day 288) were 3.8 to $5.5 \mathrm{~m}^{-3}$ for both simulations, compared to reported August to October densities of 1 to $5 \mathrm{~m}^{-3}$ (Table 3).

Mortality and growth rates were highest in the early life stages (Table 4). Eggs 

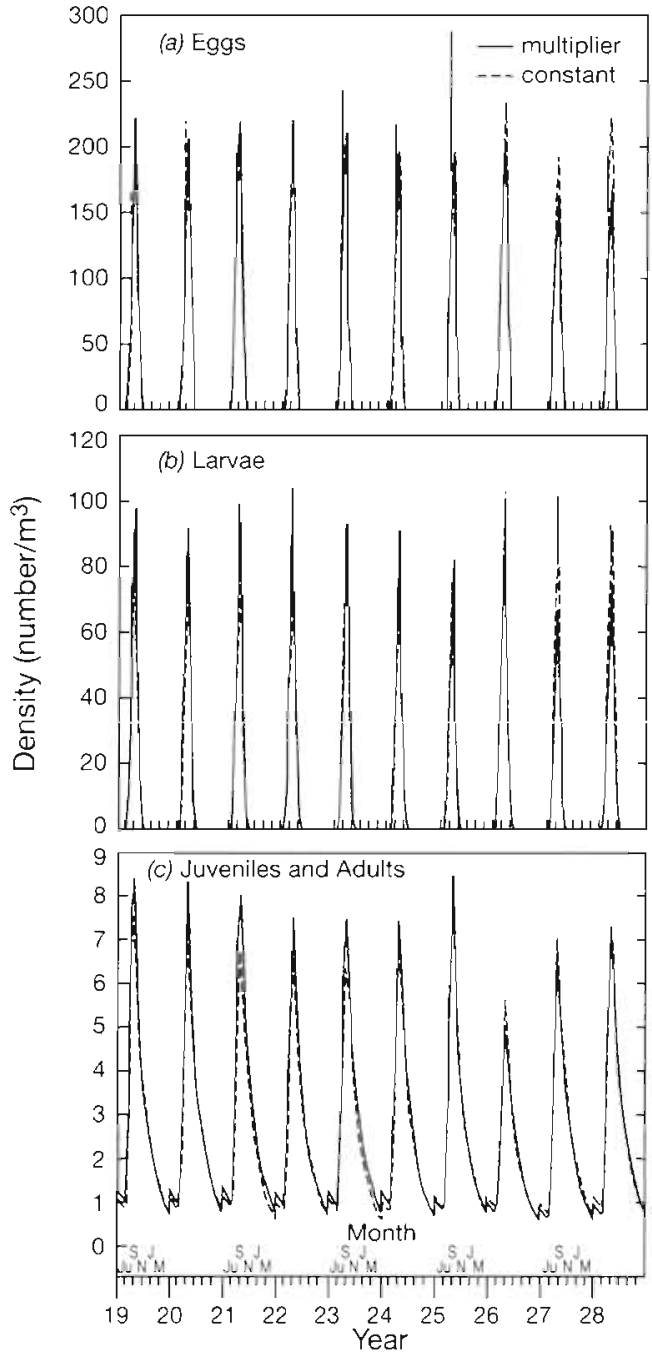

Fig. 9. Anchoa mitichilli. Simulated densities of bay anchovy by life stage ( $a$, eggs; $b$, larvae; $c$ juveniles and adults) for 10 consecutive years (Years 19 to 28) in the multiplier and constant immigration baseline simulations. Ju $=$ July, $\mathrm{S}=$ September, $N=$ November, $J=$ January, $M=$ March

and yolk-sac larvae had very short durations and high mortality rates. Survival was lowest in the larval stage $(0.7 \%)$ due to a moderate daily mortality rate coupled with a relatively long $\sim 30 \mathrm{~d}$ stage duration. More than $99.9 \%$ of the eggs died before reaching the YOY juvenile stage. Growth rates were high for both early and late surviving larvae. Bay anchovy grew from eggs to $25 \mathrm{~mm}$ in $-35 \mathrm{~d}$, and then from 25 to $\sim 50 \mathrm{~mm}$ over the remaining $265 \mathrm{~d}$ of their first year.

Simulated larval mortality rates were similar to rates observed in the field. The mortality rates of the life stages other than larvae were set at values based upon field observations. Predicted larval mortality rates resulted from the the combination of growth rates and the length-dependent mortality function (Fig. 7). Three mortality rates involving larvae were compared to reported field-based rates (Table 3). For both multiplier and constant immigration simulations, predicted mortality for: (1) egg through $10 \mathrm{~mm}$ larvae averaged $0.48 \mathrm{~d}^{-1}$ (compared to observed rates of 0.5 to $0.75 \mathrm{~d}^{-1}$ ), (2) first feeding to $10 \mathrm{~mm}$ larvae averaged $0.31 \mathrm{~d}^{-1}$ (compared to $\sim 0.35 \mathrm{~d}^{-1}$ ), and (3) the entire larval stage averaged $0.15 \mathrm{~d}^{-1}$ (compared to 0.08 to $0.18 \mathrm{~d}^{-1}$ ).

Most predicted mortality was due to the lengthbased mortality relationship. A small amount (maximum of $1.7 \%$ ) of larval starvation (weight-dependent mortality) occurred in each year of the simulations Although some mortality of juveniles and adults was caused by starvation in most years of the 50 yr multiplier and constant immigration simulations, starvation only accounted for a small fraction $(<0.5 \%$ on average) of total mortality.

Predicted growth rates of bay anchovy were realistic and similar to reported values for Chesapeake Bay. Simulated growth rates of early larvae $(<10 \mathrm{~mm})$ averaged $0.69 \mathrm{~mm} \mathrm{~d}^{-1}$ (Table 4), with a range of 0.61 to 0.71 $\mathrm{mm} \mathrm{d}^{-1}$, compared to reported rates of $\sim 0.5$ to $0.75 \mathrm{~mm}$ $\mathrm{d}^{-1}$ (Table 3). Predicted mean lengths on May 15 for the multiplier and constant immigration simulations ranged from 48 to $52 \mathrm{~mm}$ and 48 to $51 \mathrm{~mm}$ for Age 1 (compared to $\sim 52 \mathrm{~mm}$ ), from 66 to $73 \mathrm{~mm}$ and 65 to 70 $\mathrm{mm}$ for Age 2 (compared to $\sim 66 \mathrm{~mm}$ ), and from 70 to 79 $\mathrm{mm}$ and 72 to $79 \mathrm{~mm}$ for Age 3 and older (compared to $\sim 80 \mathrm{~mm}$ ) (Table 3 ).

Model-predicted diets for the multiplier immigration simulation showed anchovy progressively eating larger zooplankton as anchovy size increased (Fig. 10) Predicted diets for the constant immigration simulation

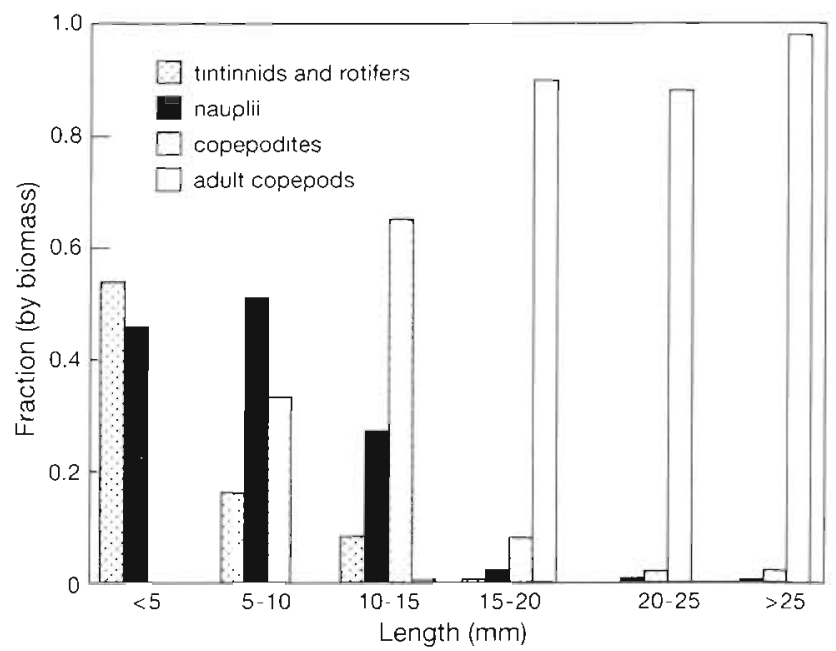

Fig. 10. Anchoa mitichilli. Predicted diets of bay anchovy by $5 \mathrm{~mm}$ length intervals for all individuals in the multiplier immigration baseline simulation. Diet composition is computed as the fraction (by biomass) of each zooplankton group averaged over all individuals during the 47 years of simulation 


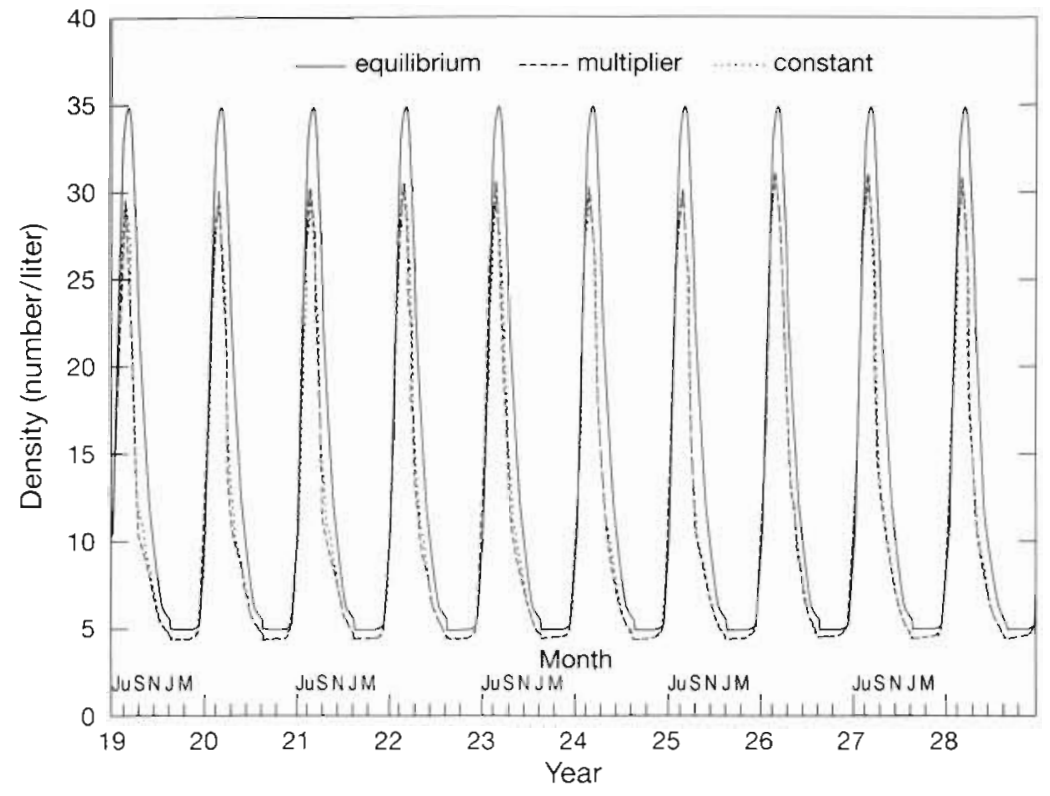

Fig. 11. Equilibrium and simulated adult copepod densities over the year for 10 consecutive years (Years 19 to 28) of the multiplier and constant immigration baseline simulations. Ju = July, $\mathrm{S}=$ September, $\mathrm{N}=$ November, $\mathrm{J}=$ January,

$$
\mathrm{M}=\mathrm{March}
$$

(not shown) were nearly identical. Very small larvae $(<5 \mathrm{~mm}$ ) consumed mostly nauplii, tintinnids and rotifers; larvae between 5 and $10 \mathrm{~mm}$ added copepodites to their diet; larvae between 10 and $15 \mathrm{~mm}$ ate mostly copepodites, and $>15 \mathrm{~mm}$ anchovy ate adult copepods. Predicted diets were expected to be qualitatively similar to reported diets of bay anchovy (Houde \& Zastrow 1991) because probability of capture curves were partially constructed from reported diet information.

Of the 4 zooplankton groups, only adult copepods were significantly reduced below equilibrium densities by anchovy grazing (Fig. 11). Current field evidence suggests that bay anchovy may significantly impact their copepod prey during the summer and fall in the Chesapeake Bay and Biscayne Bay, Florida (Table 3). However, all of the field studies indicating significant anchovy impacts on zooplankton were based upon simple static calculations applied to temporal and spatial snapshots of data; their conclusions should be viewed with caution.

Model-predicted reductions in zooplankton rely on realistic simulation of anchovy densities, zooplankton densities, zooplankton turnover, and anchovy consumption rates. We believe that den- sities of anchovy and zooplankton, and zooplankton turnover rates, in the model are reasonable. Based upon reported consumption rates of anchovy, model-simulated consumption rates also were realistic. Surviving larvae consumed prey at near $C_{\max }$ rates (i.e. $p$-values $\sim 1$ ). Average $p$-values for YOY juveniles were about 0.8 during the summer growing season; $p$-values averaged 0.25 to 0.4 for YOY juveniles overwinter, and for adults over most of the year. Simulated consumption rates of juveniles and adults combined ranged from $<2.0 \%$ body wt (BW) $\mathrm{d}^{-1}$ during the winter to a maximum of $30.0 \% \mathrm{BW}$ $\mathrm{d}^{-1}$ during the summer (Fig. 12). Fieldderived consumption rates during the summer are $<20.0 \% \mathrm{BW} \mathrm{d}^{-1}$ for adults and 30 to $40 \% \mathrm{BW} \mathrm{d}^{-1}$ for juveniles, and for adults during the winter are $\sim 2.0 \%$ BW d ${ }^{-1}$ (Table 3).

\section{Multi-year dynamics}

Model predictions of total population abundance on May 15 of each year (just before immigrants were added) under baseline conditions varied $\sim 1.5$-fold

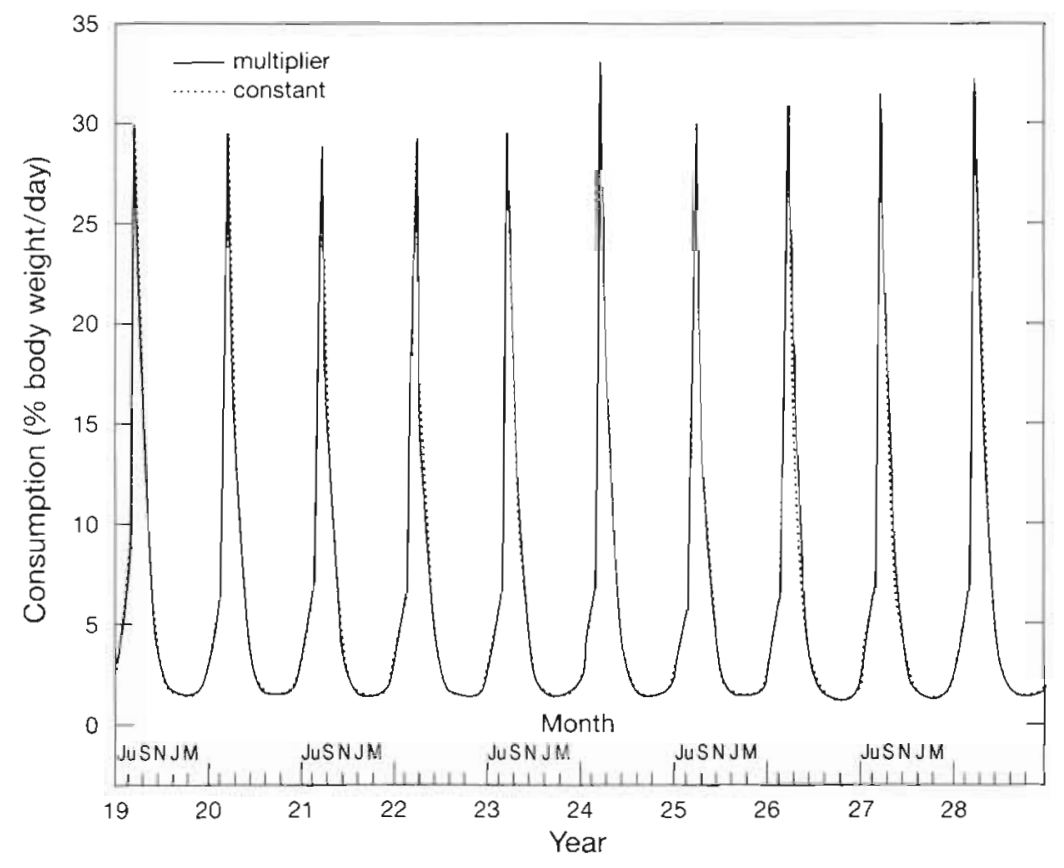

Fig. 12. Anchoa mitichilli. Predicted mean daily consumption rates $\left(\% \mathrm{BW} \mathrm{d}^{-1}\right)$ of bay anchovy (juveniles and adults combined over the year for 10 consecutive years (Years 19 to 28) of the multiplier and constant immigration baseline simulations. $\mathrm{Ju}=$ July, $\mathrm{S}=$ September, $\mathrm{N}=$ November, $\mathrm{J}=$ January, $\mathrm{M}=$ March 
Table 5. Anchoa mitichilli. Correlation coefficients from linear regression of stage-specific growth or survival rates on recruitment, numbers entering the life stage, and monthly temperature for the $47 \mathrm{yr}$ multiplier and constant immigration baseline simulations. July temperature was used for larvae and February temperature was used for YOY adults; NA denotes that none of the monthly temperatures were significantly correlated to growth rate for YOY juveniles. All $R$ values are simple correlation coefficients, except for growth rate on the numbers entering and monthly temperature, for which the $R$ value is the partial correlation coefficient showing the amount explained by numbers entering given monthly temperature is in the regression model. NS denotes $|R|<0.28$, which corresponds to $p \approx 0.05$ for $n=47$. All 4 of the partial $R$ values shown are significant ( $t$-test that regression coefficient equals zero, $\mathrm{p}<0.01$ )

\begin{tabular}{|c|c|c|c|c|c|c|}
\hline \multirow[t]{2}{*}{ Stage } & \multicolumn{3}{|c|}{ Growth rate $\left(\mathrm{mm} \mathrm{d}^{-1}\right)$} & \multicolumn{3}{|c|}{ Survival rate (fraction) } \\
\hline & Recruit & $\begin{array}{c}\text { No. } \\
\text { entering }\end{array}$ & $\begin{array}{l}\text { No. entering } \\
\text { given monthly } \\
\text { temperature }\end{array}$ & Recruit & $\begin{array}{c}\text { No. } \\
\text { entering }\end{array}$ & $\begin{array}{l}\text { Growth } \\
\text { rate }\end{array}$ \\
\hline \multicolumn{7}{|c|}{ Multiplier immigration } \\
\hline Larval & +0.52 & -0.68 & -0.47 & +0.61 & -0.65 & +0.90 \\
\hline Juvenile & -0.51 & -0.73 & NA & -0.48 & -0.81 & +0.88 \\
\hline YOY adult & -0.45 & -0.42 & -0.70 & +0.48 & NS & NS \\
\hline \multicolumn{7}{|c|}{ Constant immigration } \\
\hline Larval & +0.70 & -0.79 & -0.42 & +0.80 & -0.77 & +0.90 \\
\hline Juvenile & -0.30 & -0.60 & $\mathrm{NA}$ & -0.36 & -0.73 & +0.89 \\
\hline YOY adult & -0.28 & -0.36 & -0.30 & +0.47 & NS & NS \\
\hline
\end{tabular}

man rank correlation, implying that the relationships among survival, growth, and numbers entering were robust to the linearity assumption underlying Pearson correlation.

Slower growth rate caused longer stage duration and higher mortality. Years of high recruitment had high larval survival $(\mathrm{R}=0.61$ for muliplier and 0.80 for constant immigration simulations), which more than offset low juvenile survival $(\mathrm{R}=$ -0.48 for multiplier and $R=-0.36$ for constant immigration). Growth and survival rates of YOY adults were generally only weakly related to the number of individuals entering, and to recruitment.

Density-dependent growth also influenced annual egg production. In the multiplier immigration simulation, adult bay anchovy mean lengths were negatively related to spawner number $(R=-0.62)$ and positively related to annual number of eggs produced per spawner $(\mathrm{R}=0.61)$. For example, the year with the shortest adult mean lengths $(72 \mathrm{~mm}$ ) also had the

(maximum/minimum) for multiplier and constant immigration (Fig. 8). In agreement with observed data, the simulated anchovy population was dominated each year by Age $0+$ individuals. On average, the percent of the spawners each year that were new recruits was $74 \%$ in both baseline simulations, which is reasonable but lower than reported values of 80 to $85 \%$ (Table 3).

Density-dependent larval and juvenile growth lead to density-dependent survival (Table 5). Growth and survival rates were positively correlated for all life stages, and both were negatively related to the number of individuals entering each life stage (i.e. densitydependent) for larvae and juveniles. Temperature effects on the numbers entering and on growth rates were not the cause of density-dependent growth. Growth rates were most highly correlated to July temperature for larvae $(R=-0.68$ for multiplier immigration and $\mathrm{R}=-0.96$ for constant immigration), and to February temperature for $Y O Y$ adults $(R=0.90$ for both simulations). Warmer temperatures led to lower larval growth during the summer, and faster adult growth during the winter. None of the monthly temperatures were correlated to YOY juvenile growth rates. For both the multiplier and constant immigration simulations, the 'numbers entering' variable remained significant with the inclusion of July temperature for larvae and February temperature for YOY adults. The $\mathrm{R}$ value actually increased with the inclusion of temperature for YOY adult growth in the multiplier immigration simulation. Similar results were obtained using Spear- highest number of spawners (1034) and lowest egg per spawner $(61025)$. In contrast, the year with the longest adult mean lengths $(79 \mathrm{~mm})$ had the fourth fewest spawners (706) and the fourth highest eggs per spawner (73229). However, the increase in eggs per spawner due to longer lengths under low spawner abundances was not sufficient to offset the fewer spawners, and spawner number was positively related to total egg production ( $R=0.86)$.

Recruitment was established by the end of the larval stage. High recruitment years did not correspond to years of high first-feeder production; $R$ values between number entering the larval stage and recruitment were near zero $(0.03)$ for multiplier immigration and negative $(-0.43)$ for constant immigration simulations. Recruitment was highly correlated to the number entering the juvenile stage $(R=0.83$ for multiplier and 0.81 for constant immigration). Density-dependent juvenile growth rate lead to an inverse relationship between mean length and number of recruits ( $R=-0.53$ for multiplier and -0.34 for constant immigration).

First-year survivorship was lower in years of high egg production compared to years of lower egg production. Fewer years of high egg to Age 1 survival were predicted for the 11 years of the multiplier immigration simulation when egg production was $>6.1 \times 10^{7}$ compared to the 36 years when egg production was $<6.1 \times 10^{7}$ (Fig. 13). Similar differences in egg to Age 1 survival between years of high and low egg production were obtained for the constant immigration simulation. 


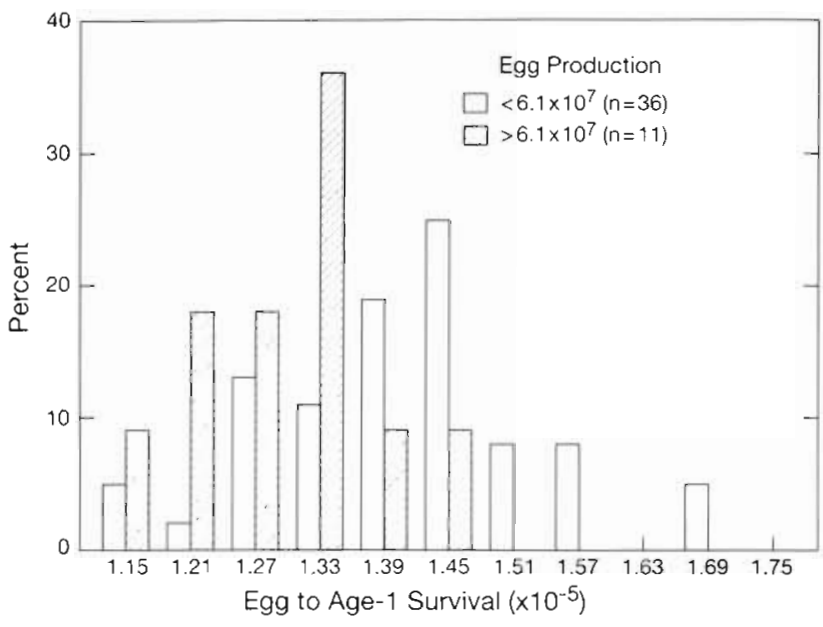

Fig. 13. Anchoa mitichilli. Frequency histograms of egg to Age 1 survival rates for the 36 years with egg production $<6.1$ $\times 10^{7}$ and the 11 years with egg production $>6.1 \times 10^{7}$ based upon the multiplier immigration baseline simulation

Lower survival in years of high egg production was mostly due to the lower survival in the juvenile life stage ( $R$ between egg production and juveniles survival was -0.73 ). Larval and YOY adult survivorships were similar between high and low egg production years (0.0067 and 0.107 vs 0.0073 and 0.109 ).

\section{DISCUSSION}

Net immigration of bay anchovy spawners into the mesohaline model box was required to produce a stable population over time. We configured the model to generate growth and mortality rates similar to the best available estimates from field data, and then determined the magnitude of net immigration necessary for long-term population stability. We represented annual immigration of female spawners as either a multiplier of model spawners or as a constant number. There is evidence of winter migration of adult anchovy from the mesohaline region to the southern reaches of Chesapeake Bay. Adult anchovy density is low during the winter months in the mesohaline region, while anchovy abundances are relatively high during December in the southern reaches of the Bay (Wang \& Houde 1995).

While invoking net immigration of bay anchovy into the mesohaline region is reasonable based on empirical information, the magnitude of immigration we determined by calibration is more questionable. The magnitudes of, and annual variability in, adult immigration to and emigration from the mesohaline region are not known. We required all individuals in the model to experience growth and mortality rates typical of the mesohaline region. If the mortality rates of some life stages are too high, or some of the individuals experience lower mortality rates than the field data average, less net immigration would be required to obtain population stability. Field data shows that some of the eggs and larvae are transported from the mesohaline region to the upper region of Chesapeake Bay (Rilling 1996) and to the subestuaries of the Chesapeake Bay (MacGregor \& Houde 1996), where mortality can be lower than in the mesohaline region. Immigration roughly doubled the number of spawners each year. Thus, without immigration, egg to Age 1 survival would need to double from calibrated rates for the population be stable. There are a variety of combinations of some subset of YOY individuals experiencing lower mortality that could result in less net immigration of spawners being required. Because we do not know how many individuals in the mesohaline region would experience lower mortality rates, and what the lower rates would be, we opted to use net immigration as a source of individuals to permit population stability. As more empirical information about the differences in growth and survival rates among the various regions of the Chesapeake Bay and its subestuaries becomes available, we will modify the model appropriately.

Model behavior appeared to be realistic based upon the similarity between model predictions and available information. Model-generated densities, mortality rates, growth rates, diets, and consumption rates were similar to reported values. Most predicted mortality was unrelated to starvation and is assumed to be attributable to predation or other sources. Anchovy consumption reduced adult copepod densities, which is plausible, given that simulated anchovy densities, zooplankton densities, zooplankton turnover rates, and anchovy consumption rates were realistic. Model predictions were similar between multiplier and constant immigraton simulations.

Density-dependent effects on growth and survival rates were predicted for both the multiplier and constant immigration simulations. Growth and survival rates of larvae and juveniles were positively correlated, and both were negatively related to the number entering each of the life stages. The negative relationships between growth rates and numbers entering were not due to temperature effects, as the number entering variable remained significant in multiple regression models that included monthly temperatures. Years of high recruitment were not necessarily years of high first-feeder abundances, but rather were years of high larval survival that offset density-dependent juvenile survival. Years of high egg production ultimately resulted in decreased overall first-year survival. Luo (1991) reported a significant Ricker spawner-recruit relationship for bay anchovy in lower 
Chesapeake Bay, also implying reduced recruitment (survival) in years of high egg production. An inverse relationship between mean length and number of recruits was predicted $(R=-0.53$ for multipler immigration and -0.34 for constant immigration). However, model-generated differences in mean lengths of Age 0 anchovy in October had no effect on subsequent simulated overwinter mortality rates. The degree of sizedependence of adult anchovy mortality or overwintering mortality was not clear from the available empirical data.

Simulated anchovy population abundances exhibited relatively small interannual variation (1.5-fold) compared to observations. We accepted the model simulations because good, long-term estimates of annual bay anchovy abundances are not available. We could generate realistic variation by randomly varying any number of factors in the model (e.g immigration, predation mortality), but we lack adequate information to assign, with any degree of confidence, the relative contributions of these factors to anchovy variation. Imposing additional, necessarily random, variation in factors affecting anchovy population variation would simply add noise to model analyses based on longterm means. Data to quantify interannual variation of bay anchovy abundances and to permit mesoscale (e.g. upper Bay, subestuaries) specification of spatial variation in prey densities, predation pressure, and bay anchovy abundances, growth rates, and survival rates presently are being collected. Additional model analyses designed to examine how temporal and spatial variation in different combinations of factors can lead to realistic variation in anchovy population abundances are warranted.

Two major features of the present version of the bay anchovy model are the simulation of a single spatial box with a forced net immigration of spawners each year and the static (density-independent) representation of spawning and mortality processes. A coarse, multi-box version of the bay anchovy model would permit explicit simulation of spawning migration, movement, and differential growth and survival among the sub-esturaries and the major regions of the Bay. However, immigration would still be an issue in a Bay-wide model, because bay anchovy also may migrate between the open ocean and the Chesapeake Bay. Representing spawning (number of batches, fecundity) and mortality rates of life stages as dynamic functions of anchovy densities would allow further exploration of bay anchovy population dynamics. But, explicit specification of the functional forms for the dependence of spawning and mortality on density is highly uncertain with existing data.

Cowan et al. (1999) and Wang et al. (1997) circumvented representing spawning and mortality rates as functions of anchovy density and used the 1 -box model to investigate aspects of bay anchovy population dynamics and production. Cowan et al. (1999) demonstrated that: (1) density-dependent effects on prey alone had a limiting buffering effect against a 50\% reduction in larval-stage survival, (2) the effects of losses of larvae on future production were orders of magnitude higher for larvae and juveniles compared to eggs and yolk-sac larvae, and (3) realistic, simultaneous changes in spawning intensity and post-larval mortality rates can offset a $50 \%$ decrease in larvalstage survival. Wang et al. (1997) used the anchovy model to show how delayed and bimodal spawning peaks affected long-term population dynamics that are moderated by density-dependent survival and growth.

We believe that individual-based models offer a promising approach for simulating the population and community dynamics of fish and other taxa (DeAngelis et al. 1994, Rose et al. 1996). Many processes in fish are size-based (Miller et al. 1988, Crowder et al. 1992, Sogard 1997), and individual differences in size and other attributes (e.g. timing of hatch) can have significant effects on subsequent growth, survival, and reproduction (Cowan et al. 1997, Tyler \& Rose 1997, Van Winkle et al. 1997). Representing the effects of inter-individual variation can only be approximated in the more traditional stage or age-based population modeling approaches. Tracking individuals as the fundamental biological unit in individual-based models allows for easy representation of size-based processes and interactions, and straightforward scaling of relatively subtle, but important, differences in individual attributes to the population level

Acknowledgements. Research sponsored by the Electric Power Research Institute under contract RP2932-2 (DOE No. ERD-87-672) with the U.S. Department of Energy, under Contract No. DE-AC05-96OR22464 with Lockheed Martin Energy Research Corp. This is publication No. 4780 of the Environmental Sciences Division, ORNL. E.D.H.'s participation was supported by NSF Grants OCE-92-03307 and OCE95-21512. S.-B.W's participation was funded by a fellowship from the Electric Power Research Institute (EPRI) through the American Sportfishing Association EPRI Fellowship Program

\section{LITERATURE CITED}

Baird D, Ulanowicz RE (1989) The seasonal dynamics of the Chesapeake Bay ecosystem. Ecol Monogr 59:329-364

Blaxter JHS (1986) Development of sense organs and behaviour of teleost larvae with special reference to feeding and predator avoidance. Trans Am Fish Soc 115:98-114

Boehlert GW, Morgan JB (1985) Turbidity enhances feeding abilities of larval Pacific herring, Clupea harengus pallasi. Hydrobiol 123:161-170

Breck JE, Gitter MJ (1983) Effect of tish size on the reactive distance of bluegill (Lepomis macrochirus) sunfish. Can J Fish Aquat Sci 40:162-167 
Brownlee DC, Jacobs F (1987) Chapter 12: Mesozooplankton and microzooplankton in the Chesapeake Bay. In: Mjumdar SK, Hall LW, Austin HM (eds) Contaminant problems and management of living Chesapeake Bay resources. Pennsylvania Academy of Science, Easton, p 217-269

Castro LR, Cowen RK (1991) Environmental factors affecting the early life history of bay anchovy Anchoa mitchilli in Great South Bay, New York. Mar Ecol Prog Ser 76: $235-247$

Chesney EJ (1989) Estimating the food requirements of striped bass larvae Morone saxatilis: effects of light, turbidity and turbulence. Mar Ecol Prog Ser 53:191-200

Cowan JH, Houde ED (1990) Growth and survival of bay anchovy (Anchoa mitchilli) larvae in mesocosm enclosures. Mar Ecol Prog Ser 68:47-57

Cowan JH, Rose KA, Houde ED (1997) Size-based foraging success and vulnerability to predation: selection of survivors in individual-based models of larval fish populations. In: Chambers R, Trippel E (eds) Early life history and recruitment in fish populations. Chapman and Hall, New York, p 357-386

Cowan JH, Rose KA, Houde ED, Young J (1999) Modeling effects of increased larval mortality on bay anchovy population dynamics in the mesohaline Chesapeake Bay: evidence for compensatory reserve. Mar Ecol Prog Ser 185: $133-146$

Crowder LB, Rice JA, Miller TJ, Marschall EA (1992) Empirical and theoretical approaches to size-based interactions and recuitment variability in fishes. In: DeAngelis DL, Gross LJ (eds) Individual-based models and approaches in ecology: population, communities, and ecosystems. Chapman and Hall, New York, p 237-255

Dalton PD (1987) Ecology of bay anchovy (Anchoa mitchilli) eggs and larvae in the mid-Chesapeake Bay. MSc thesis, University of Maryland, College Park

DeAngelis DL, Rose KA, Huston MA (1994) Individual-oriented approaches to modeling populations and communities. In: Levin SA (ed) Frontiers in mathematical biology. Lecture Notes in Biomathematics. Vol 100. Springer-Verlag, New York, p 390-410

Dorsey SE (1993) Daily variability in mortality of bay anchovy (Anchoa mitchilli) eggs and yolk-sac larvae in Chesapeake Bay, USA. MSc thesis, University of Maryland, College Park

Dorsey SE, Houde ED, Gamble JC (1996) Cohort abundances and daily variability in mortality of eggs and yolk-sac larvae of bay anchovy, Anchoa mitchilli, in Chesapeake Bay. Fish Bull US 94:257-267

Dumont HJ, Van de Velde I, Dumont S (1975) The dry weight estimate of biomass in a selection of cladocera, copepoda and rotifera from the plankton, periphyton and benthos of continental waters. Oecologia 19:75-97

Durbin AG, Durbin EG (1981) Standing stock and estimated production rates of phytoplankton and zooplankton in Narragansett Bay, Rhode Island. Estuaries 4:24-41

Govoni JJ, Boehlert GW, Watanabe Y (1986) The physiology of digestion in fish larvae. Environ Biol Fish 16:59-77

Guma'a SA (1982) Retinal development and retinomotor responses in perch, Perca fluviatilis L. J Fish Biol 20:611-618

Hairston NG, Li KT, Easter SS (1982) Fish vision and the detection of planktonic prey. Science 218:1240-1242

Hart PJB (1986) Foraging in teleost fishes. In: Pitcher TJ (ed) The behavior of teleost fishes. The Johns Hopkins University Press, Baltimore, Maryland p 211-235

Hartman KJ, Brandt SB (1995) Comparative energetics and the development of bioenergetics models for sympatric estuarine piscivores. Can J Fish Aquat Sci 52:1647-1666
Heinle DR (1966) Production of a calanoid copepod, Acartia tonsa, in the Patuxent River estuary. Chesapeake Sci 7 : $59-74$

Hewett SW, Johnson BJ (1987) A generalized bioenergetics model of fish growth for microcomputers. University of Wisconsin Sea Grant Institute, WIS-SG-87-245, Madison

Horwitz RJ (1987) Fish. In: Heck KL (ed) Ecological studies in the middle reach of Chesapeake Bay. Lecture Notes on Coastal and Estuarine Studies 23. Springer-Verlag, Berlin, p $167-224$

Houde ED (1974) Effects of temperature and delayed feeding on growth and survival of larvae of three species of subtropical marine fishes. Mar Biol 26:271-285

Houde ED (1987) Fish early life history dynamics and recruitment variability. Am Fish Soc Symp 2:17-29

Houde ED, Gamble IC, Dorsey SE, Cowan JH (1994) Drifting mesocosms: the influence of gelatinous zooplankton on mortality of bay anchovy Anchoa mitchilli eggs and yolksac larvae. ICES J Mar Sci 51:383-394

Houde ED, Lovdal JA (1984) Seasonality of occurrence, foods and food preferences of ichthyoplankton in Biscayne Bay, Florida. Estuar Coast Shelf Sci 18:403-419

Houde ED, Schekter RC (1980) Feeding by marine fish larvae developmental and functional responses. Environ Biol Fish 5:315-334

Houde ED. Schekter RC (1981) Growth rates, rations and cohort consumption of marine fish larvae in relation to prey concentrations. Rapp PV Réun Cons Int Explor Mer 178:441-453

Houde ED, Schekter RC (1983) Oxygen uptake and comparative energetics among eggs and larvae of three subtropical marine fishes. Mar Biol 72:283-293

Houde ED, Zastrow CE (1991) Bay anchovy, Anchoa mitchilli. In: Funderburk SL, Mihursky JA, Jordan SJ, Riley D (eds) Habitat requirements for Chesapeake Bay living resources, 2nd edn. Living Resources Subcommittee, Chesapeake Bay Program, Annapolis, MD, p 8-1-8-14

Hughes RN (1980) Optimal foraging theory in the marine context. Oceanogr Mar Biol Annu Rev 18:423-481

Huntley ME, Lopez MDG (1992) Temperatuure-dependent production of marine copepods: a global synthesis. Am Nat 140:201-242

Johnson TB, Evans DO (1991) Behavior, energetics, and associated mortality of young-of-the-year white perch (Morone americana) and yellow perch (Perca flavescens) under simulated winter conditions. Can J Fish Aquat Sci 48:672-680

Klebasko MJ (1991) Feeding ecology and daily ration of bay anchovy (Anchoa mitchilli) in the mid-Chesapeake Bay. MSc thesis, University of Maryland, College Park

Krebs JR (1978) Optimal foraging: decision rules for predators. In: Krebs JR, Davies NB (eds) Behavioural ecology: an evolutionary approach. Sinauer, Sunderland, MA, p 23-63

Leak JC (1984) Growth and survival of bay anchovy (Anchoa mitchilli) larvae in north Biscayne Bay, Florida. PhD dissertation, University of Miami, Coral Cables

Leak JC, Houde ED (1987) Cohort growth and survival of bay anchovy Anchoa mitchilli larvae in Biscayne Bay, Florida Mar Ecol Prog Ser 37:109-122

Letcher BH, Rice JA, Crowder LB, Rose KA (1996) Variability in survival of larval fishes: disentangling components of variance with a generalized individual-based model. Can $J$ Fish Aquat Sci 53:787-801

Loos JJ, Perry ES (1991) Larval migration and mortality rates of bay anchovy in the Patuxent river. In: Hoyt RD (ed) Larval fish recruitment and research in the Americas: Proceedings of the $13^{\text {th }}$ annual larval fish conference. NOAA Technical Report NMFS 95, p 65-76 
Luo J (1991) Life history of the bay anchovy, Anchoa mitchilli, in Chesapeake Bay. PhD dissertation, College of William and Mary, Williamsburg, VA

Luo J, Brandt SB (1993) Bay anchovy Anchoa mitchilli production and consumption in mid-Chesapeake Bay based on a bioenergetics model and acoustic measures of fish abundance. Mar Ecol Prog Ser 98:223-236

Luo J, Musick JA (1991) Reproductive biology of the bay anchovy in Chesapeake Bay. Trans Am Fish Soc 120:701-710

MacGregor JM, Houde ED (1996) Onshore-offshore pattern and variability in distribution and abundance of bay anchovy, Anchoa mitchilli, eggs and larvae in Chesapeake Bay. Mar Ecol Prog Ser 138:15-25

Miller TJ, Crowder LB, Rice JA, Marschall EA (1988) Larval size and recruitment mechanisms in fishes: toward a conceptual framework. Can J Fish Aquat Sci 45:1657-1670

Newberger TA (1989) Relative abundance, age, growth and mortality of bay anchovy (Anchoa mitchilli) in the midChesapeake Bay. MSc thesis, University of Maryland, College Park

Noakes DLG, Godin JGJ (1988) Ontogeny of behavior and concurrent developmental changes in sensory systems in teleost fishes. In: Hoar WS, Randall DJ (eds) Fish physiology, Vol 11B, Viviparity and posthatching juveniles. Academic Press, New York, p 345-395

Olson MM (1987) Zooplankton. In: Heck KL (ed) Ecological studies in the middle reach of Chesapeake Bay. Lecture Notes on Coastal and Estuarine Studies 23. Springer-Verlag, New York, p 38-81

Polgar TT, Turner MA, Summers JK (1988) Effect of power plant entrainment on the population dynamics of the bay anchovy (Anchoa mitchilli). Ecol Model 41:201-218

PSE\&G (Public Service Electric and Gas Company) (1984) Bay anchovy (Anchoa mitchilli): A synthesis of information of natural history, with respect to occurence in the Delaware River and Estuary and involvement with the Salem Generating Station. 316 (b) Demonstration, Appendix XII, Bay anchovy, Vols 1 and 2. PSE\&G, Newark, NJ

Rilling GC (1996) Regional and temporal variability in growth, mortality, and age structure of bay anchovy (Anchoa mitchilli) eggs and larvae in the Chesapeake Bay. MSc thesis, University of Maryland, College Park

Rogers BA, Westin DT (1981) Laboratory studies on effects of temperature and delayed initial feeding on development of striped bass larvae. Trans Am Fish Soc 110:100-110

Rose KA, Christensen SW, DeAngelis DL (1993) Individualbased modeling of populations with high mortality: a new method based on following a fixed number of model individuals. Ecol Model 68:273-293

Rose KA, Tyler JA, SinghDermot D, Rutherford E (1996) Multispecies modelling of fish populations. In: Megrey B, Moksness $\mathrm{E}$ (eds) Computers in fisheries research. Chapman and Hall, New York, p 194-222

Rosenthal H, Hempel G (1970) Experimental studies in feeding and food requirements of herring larvae (Clupea harengus L.). In: Steele JH (ed) Marine food chains. Oliver and Boyd, Edinburgh, p 344-364

Editorial responsibility: Kenneth Heck Jr (Contributing Editor), Dauphin Island, Alabama, USA
Shuter BJ, Ihssen PE, Wales DL, Snucins EJ (1989) The effects of temperature, $\mathrm{pH}$, and water hardness on winter starvation of young-of-the-year smallmouth bass, Micropterus dolomieui Lacepede. J Fish Biol 35:765-780

Sogard SM (1997) Size-selective mortality in the juvenile stage of teleost fishes: a review. Bull Mar Sci 60: $1129-1157$

Summers JK (1989) Simulating the indirect effects of power plant entrainment losses on an estuarine ecosystem. Ecol Model 49:31-47

Tucker JW (1989) Energy utilization in bay anchovy, Anchoa mitchilli, and black sea bass, Centropristis striata striata, eggs and larvae. Fish Bull US 78:279-293

Tyler JA, Rose KA (1997) Effects of individual habitat selection in a heterogenous environment on fish cohort survivorship: a modelling analysis. J Anim Ecol 66:122-136

Vazquez AV (1989) Energetics, trophic relationships and chemical composition of bay anchovy, Anchoa mitchilli, in the Chesapeake Bay. MSc thesis, University of Maryland, College Park

Van Winkle W, Rose KA, Shuter BJ, Jager HI, Holcomb BD (1997) Effects of climatic temperature change on growth, survival, and reproduction of rainbow trout: predictions from a simulation model, Can J Fish Aquat Sci 54: $2526-2542$

Verity PG (1987) Abundance, community composition, size distribution, and production rates of tintinnids in Narragansett Bay, Rhode Island. Estuar Coast Shelt Sci 24 $671-690$

Vinyard GL, O'Brien WJ (1976) Effects of light and turbidity on the reactive distance of bluegill (Lepomis macrochirus). J Fish Res Bd Can 33:2845-2849

Vouglitois JJ, Able KW, Kurtz RJ, Tighe KA (1987) Life history and population dynamics of the bay anchovy in New Jersey. Trans Am Fish Soc 116:141-153

Wang SB (1992) Abundance, relative biomass, production and energy storage of bay anchovy, Anchoa mitchilli, in the Chesapeake Bay. MSc thesis, University of Maryland, College Park

Wang SB, Cowan JH, Rose KA, Houde ED (1997) Variability in recruitment and production potential of bay anchovy, Anchoa mitchilli, in mid-Chesapeake Bay. J Fish Biol 51 (Suppl A): $101-120$

Wang SB, Houde ED (1995) Distribution, relative abundance, biomass, and production of bay anchovy Anchoa mitchilli, in the Chesapeake Bay. Mar Ecol Prog Ser 121:27-38

Wanzenbock J, Schiemer F (1.989) Prey detection in cyprinids during early development. Can J Fish Aquat Sci 46 : 995-1001

Winemiller KO, Rose KA (1992) Patterns of life-history diversification in North American fishes: implications for population regulation. Can J Fish Aquat Sci 49: $2196-2218$

Zastrow CE, Houde ED, Morin LG (1991) Spawning, fecundity and hatch-date frequency of bay anchovy (Anchoa mitchilli) in mid-Chesapeake Bay. Mar Ecol Prog Ser 73: $161-171$

Submitted: September 22, 1997; Accepted: December 30, 1998 Proofs received from author(s): July 27, 1999 